\title{
LEVEL II SCOUR ANALYSIS FOR BRIDGE 27 (STJOTH00080027) on TOWN HIGHWAY 8, crossing the SLEEPERS RIVER, ST. JOHNSBURY, VERMONT
}

Open-File Report 97-779

Prepared in cooperation with

VERMONT AGENCY OF TRANSPORTATION

and

FEDERAL HIGHWAY ADMINISTRATION

U.S. Department of the Interior

U.S. Geological Survey

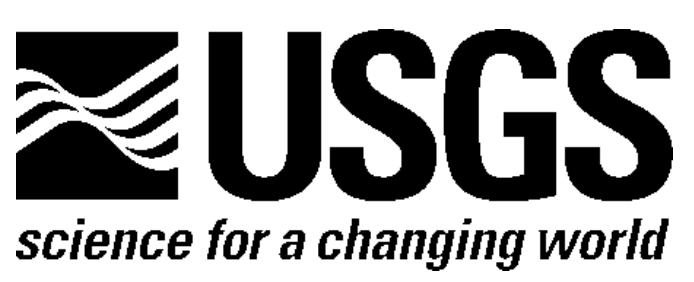




\section{LEVEL II SCOUR ANALYSIS FOR BRIDGE 27 (STJOTH00080027) on TOWN HIGHWAY 8, crossing the SLEEPERS RIVER, ST. JOHNSBURY, VERMONT \\ By MICHAEL A. IVANOFF}

U.S. Geological Survey Open-File Report 97-779

Prepared in cooperation with

VERMONT AGENCY OF TRANSPORTATION

and

FEDERAL HIGHWAY ADMINISTRATION 


\title{
U.S. DEPARTMENT OF THE INTERIOR BRUCE BABBITT, Secretary
}

\author{
U.S. GEOLOGICAL SURVEY \\ Mark Schaefer, Acting Director
}

For additional information write to:

District Chief

U.S. Geological Survey 361 Commerce Way

Pembroke, NH 03275-3718
Copies of this report may be purchased from:

U.S. Geological Survey

Branch of Information Services

Open-File Reports Unit

Box 25286

Denver, CO 80225-0286 


\section{CONTENTS}

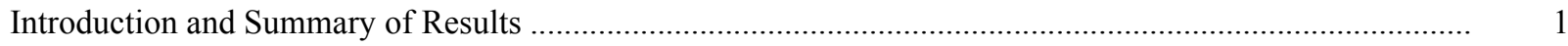

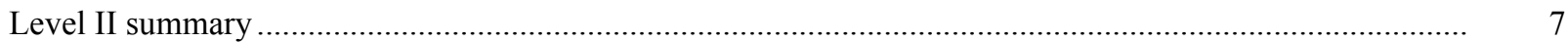

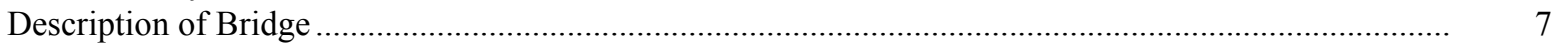

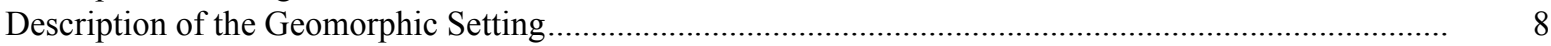

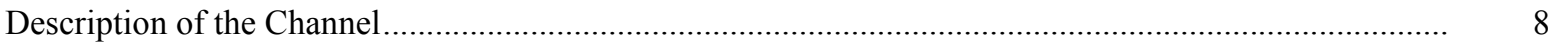

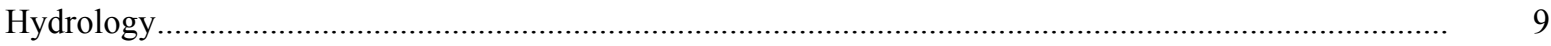

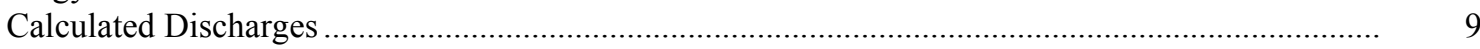

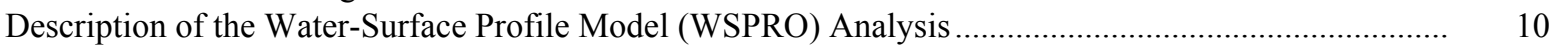

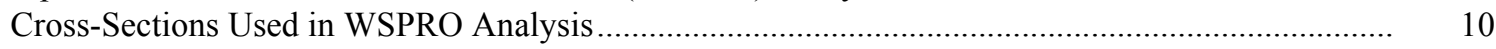

Data and Assumptions Used in WSPRO Model ...................................................................... 11

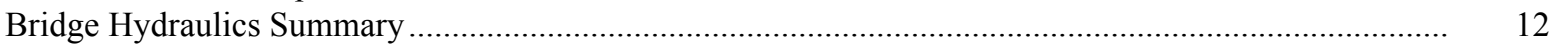

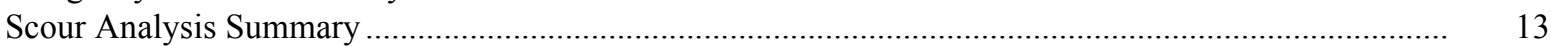

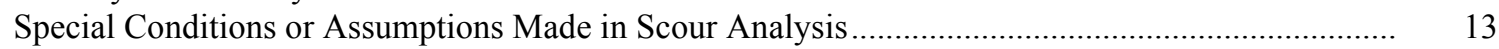

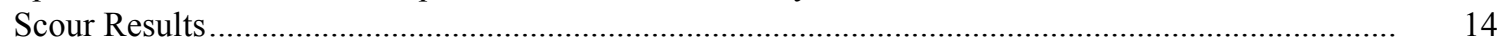

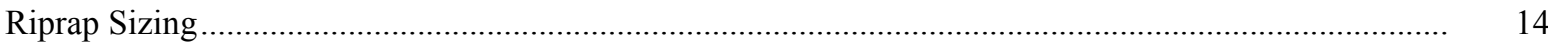

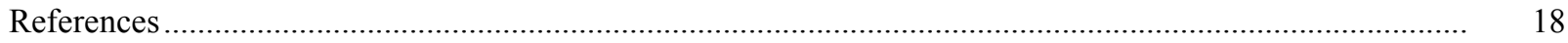

Appendixes:

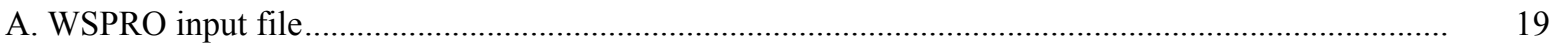

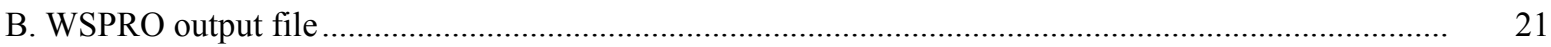

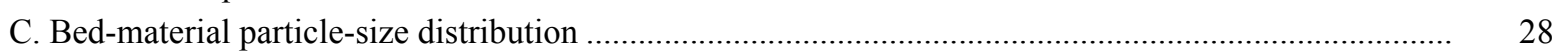

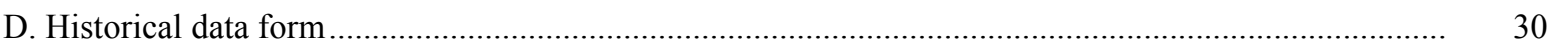

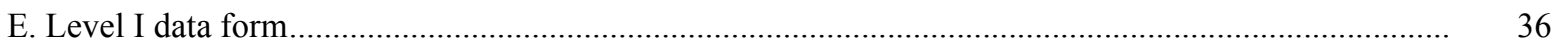

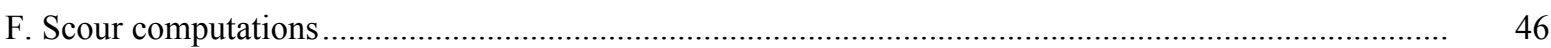

\section{FIGURES}

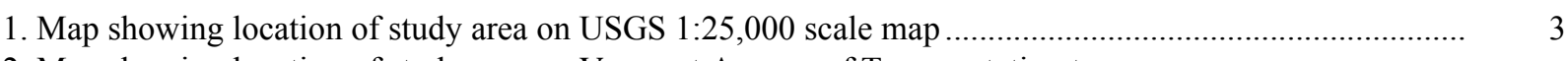

2. Map showing location of study area on Vermont Agency of Transportation town
highway map

3. Structure STJOTH00080027 viewed from upstream (August 10, 1995) ................................................ 5

4. Downstream channel viewed from structure STJOTH00080027 (August 10, 1995) .............................. 5

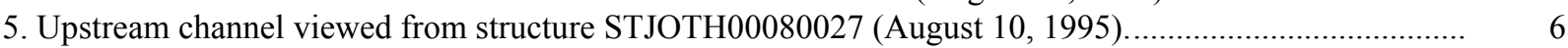

6. Structure STJOTH00080027 viewed from downstream (August 10, 1995). ....................................... 6

7. Water-surface profiles for the 100- and 500-year discharges at structure

STJOTH00080027 on Town Highway 8 crossing the Sleepers River,

St. Johnsbury, Vermont.

8. Scour elevations for the 100- and 500-year discharges at structure

STJOTH00080027 on Town Highway 8, crossing the Sleepers River,

St. Johnsbury, Vermont.

\section{TABLES}

1. Remaining footing/pile depth at abutments for the 100-year discharge at structure

STJOTH00080027 on Town Highway 8, crossing the Sleepers River,

St. Johnsbury, Vermont.

2. Remaining footing/pile depth at abutments for the 500-year discharge at structure

STJOTH00080027 on Town Highway 8, crossing the Sleepers River,

St. Johnsbury, Vermont. 


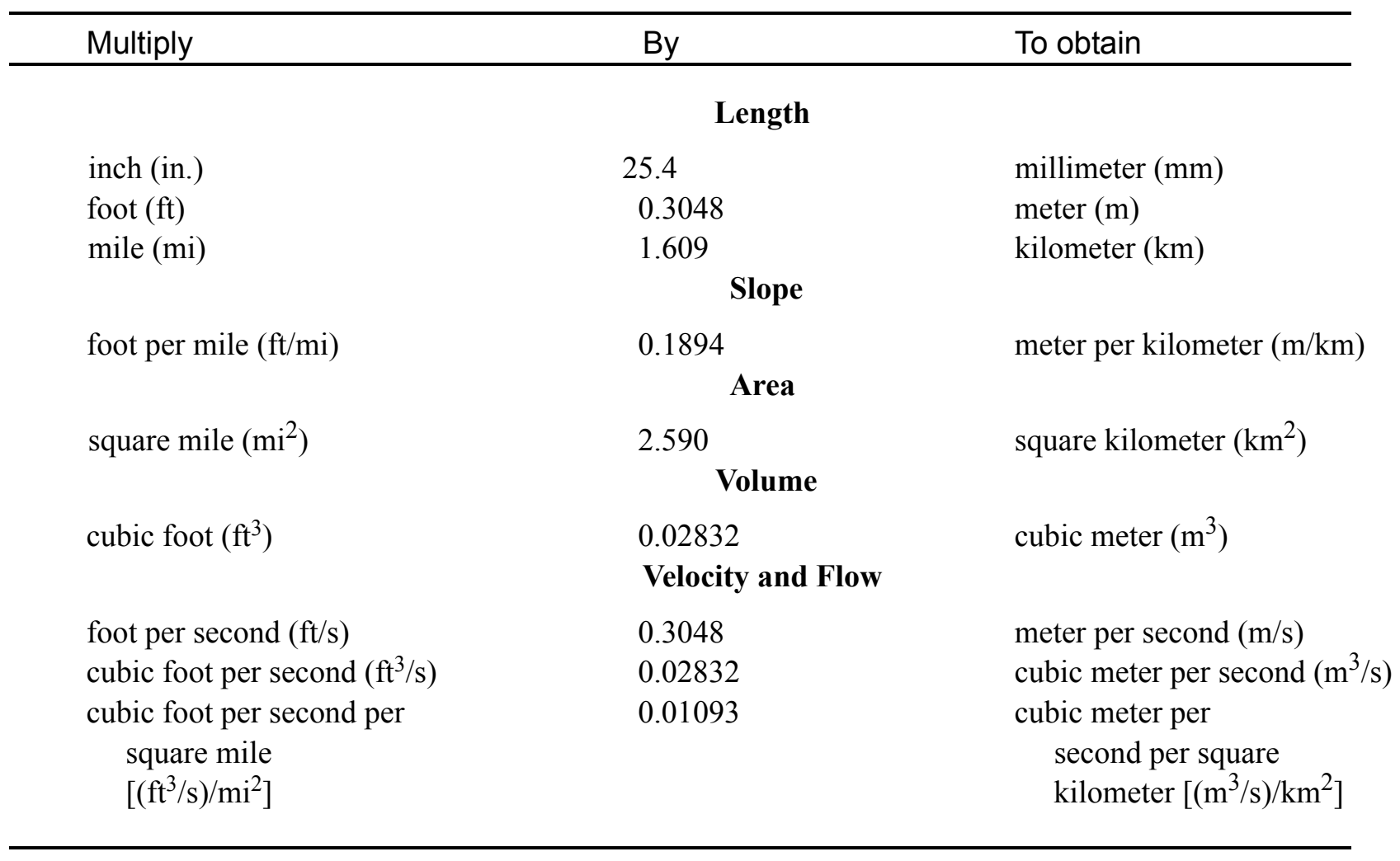

\section{OTHER ABBREVIATIONS}

$\begin{array}{lrlr}\mathrm{BF} & \text { bank full } & \text { LWW } & \text { left wingwall } \\ \mathrm{cfs} & \text { cubic feet per second } & \text { MC } & \text { main channel } \\ \mathrm{D}_{50} & \text { median diameter of bed material } & \text { RAB } & \text { right abutment } \\ \mathrm{DS} & \text { downstream } & \text { RABUT } & \text { face of right abutment } \\ \mathrm{elev} & \text { elevation } & \text { RB } & \text { right bank } \\ \mathrm{f} / \mathrm{p} & \text { flood plain } & \text { ROB } & \text { right overbank } \\ \mathrm{ft}^{2} & \text { square feet } & \text { RWW } & \text { right wingwall } \\ \mathrm{ft} / \mathrm{ft} & \text { feet per foot } & \text { TH } & \text { town highway } \\ \mathrm{JCT} & \text { junction } & \text { UB } & \text { under bridge } \\ \mathrm{LAB} & \text { left abutment } & \text { US } & \text { upstream } \\ \mathrm{LABUT} & \text { face of left abutment } & \text { USGS } & \text { United States Geological Survey } \\ \text { LB } & \text { left bank } & \text { VTAOT } & \text { Vermont Agency of Transportation } \\ \text { LOB } & \text { left overbank } & \text { WSPRO } & \text { water-surface profile model } \\ \text { FEMA } & \text { Federal Emergency Management Agency } & & \end{array}$

In this report, the words "right" and "left" refer to directions that would be reported by an observer facing downstream. Sea level: In this report, "sea level" refers to the National Geodetic Vertical Datum of 1929-- a geodetic datum derived from a general adjustment of the first-order level nets of the United States and Canada, formerly called Sea Level Datum of 1929.

In the appendices, the above abbreviations may be combined. For example, USLB would represent upstream left bank. 


\title{
LEVEL II SCOUR ANALYSIS FOR BRIDGE 27 (STJOTH00080027) ON TOWN HIGHWAY 8, CROSSING THE SLEEPERS RIVER, ST. JOHNSBURY, VERMONT
}

\author{
By Michael A. Ivanoff
}

\section{INTRODUCTION AND SUMMARY OF RESULTS}

This report provides the results of a detailed Level II analysis of scour potential at structure STJOTH00080027 on Town Highway 8 crossing the Sleepers River, St. Johnsbury, Vermont (figures 1-8). A Level II study is a basic engineering analysis of the site, including a quantitative analysis of stream stability and scour (U.S. Department of Transportation, 1993). Results of a Level I scour investigation also are included in Appendix E of this report. A Level I investigation provides a qualitative geomorphic characterization of the study site. Information on the bridge, gleaned from Vermont Agency of Transportation (VTAOT) files, was compiled prior to conducting Level I and Level II analyses and is found in Appendix D.

The site is in the New England Upland section of the New England physiographic province in northeastern Vermont. The $40.4-\mathrm{mi}^{2}$ drainage area is in a predominantly rural and forested basin. In the vicinity of the study site, the surface cover is forest on the upstream right bank with some pasture on the upstream left bank. The downstream right overbank cover is comprised of cut grass, trees and shrubs while the immediate banks have dense woody vegetation. The downstream left bank is forested with some pasture.

In the study area, the Sleepers River has an incised, sinuous channel with a slope of approximately $0.007 \mathrm{ft} / \mathrm{ft}$, an average channel top width of $72 \mathrm{ft}$ and an average bank height of $5 \mathrm{ft}$. The channel bed material ranges from gravel to cobble with a median grain size $\left(\mathrm{D}_{50}\right)$ of $48.5 \mathrm{~mm}(0.159 \mathrm{ft})$. The geomorphic assessment at the time of the Level I and Level II site visit on August 10, 1995, indicated that the reach was stable.

The Town Highway 8 crossing of the Sleepers River is a 74-ft-long, two-lane bridge consisting of one 71-foot steel-beam span (Vermont Agency of Transportation, written communication, March 28, 1995). The opening length of the structure parallel to the bridge face is $68 \mathrm{ft}$. The bridge is supported by vertical, concrete abutments with wingwalls. The channel is skewed approximately 50 degrees to the opening while the computed openingskew-to-roadway is 45 degrees. The VTAOT database states the opening-skew-to-roadway as 30 degrees. 
A scour hole $2.5 \mathrm{ft}$ deeper than the mean thalweg depth was observed along the right abutment during the Level I assessment. There is also a three to four foot deep scour hole in the channel adjacent to the upstream right wingwall. The scour protection at the site included type-3 stone fill (less than 48 inches diameter) at the upstream end of the upstream left wingwall, at the downstream end of the downstream right wingwall, and along the downstream left bank. There was also type-2 stone fill (less than 36 inches diameter) at the downstream end of the downstream left wingwall, along the upstream left bank, and along the downstream right bank. Additional details describing conditions at the site are included in the Level II Summary and Appendices D and E.

Scour depths and recommended rock rip-rap sizes were computed using the general guidelines described in Hydraulic Engineering Circular 18 (Richardson and others, 1995) for the 100- and 500-year discharges. In addition, the incipient roadway-overtopping discharge is determined and analyzed as another potential worst-case scour scenario. Total scour at a highway crossing is comprised of three components: 1) long-term streambed degradation; 2) contraction scour (due to accelerated flow caused by a reduction in flow area at a bridge) and; 3 ) local scour (caused by accelerated flow around piers and abutments). Total scour is the sum of the three components. Equations are available to compute depths for contraction and local scour and a summary of the results of these computations follows.

Contraction scour computed for all modelled flows was zero ft. Abutment scour ranged from 6.2 to $9.7 \mathrm{ft}$. The worst-case abutment scour occurred at the 100-year discharge at the right abutment and at the 500-year discharge at the left abutment. Additional information on scour depths and depths to armoring are included in the section titled "Scour Results". Scoured-streambed elevations, based on the calculated scour depths, are presented in tables 1 and 2. A cross-section of the scour computed at the bridge is presented in figure 8. Scour depths were calculated assuming an infinite depth of erosive material and a homogeneous particle-size distribution.

It is generally accepted that the Froehlich equation (abutment scour) gives "excessively conservative estimates of scour depths" (Richardson and others, 1995, p. 47). Usually, computed scour depths are evaluated in combination with other information including (but not limited to) historical performance during flood events, the geomorphic stability assessment, existing scour protection measures, and the results of the hydraulic analyses. Therefore, scour depths adopted by VTAOT may differ from the computed values documented herein. 


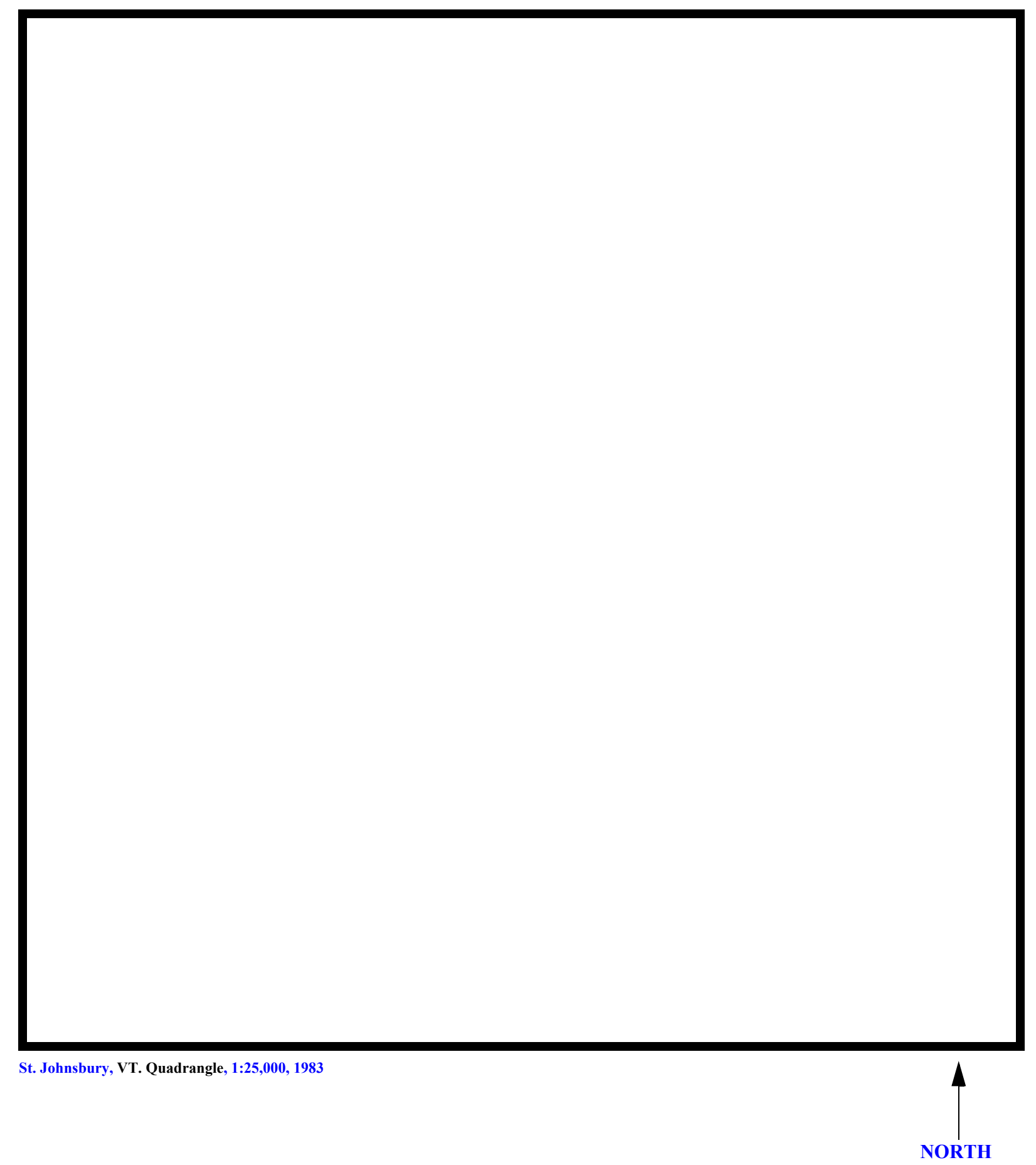

Figure 1. Location of study area on USGS 1:24,000 scale map. 
Figure 2. Location of study area on Vermont Agency of Transportation town highway map. 

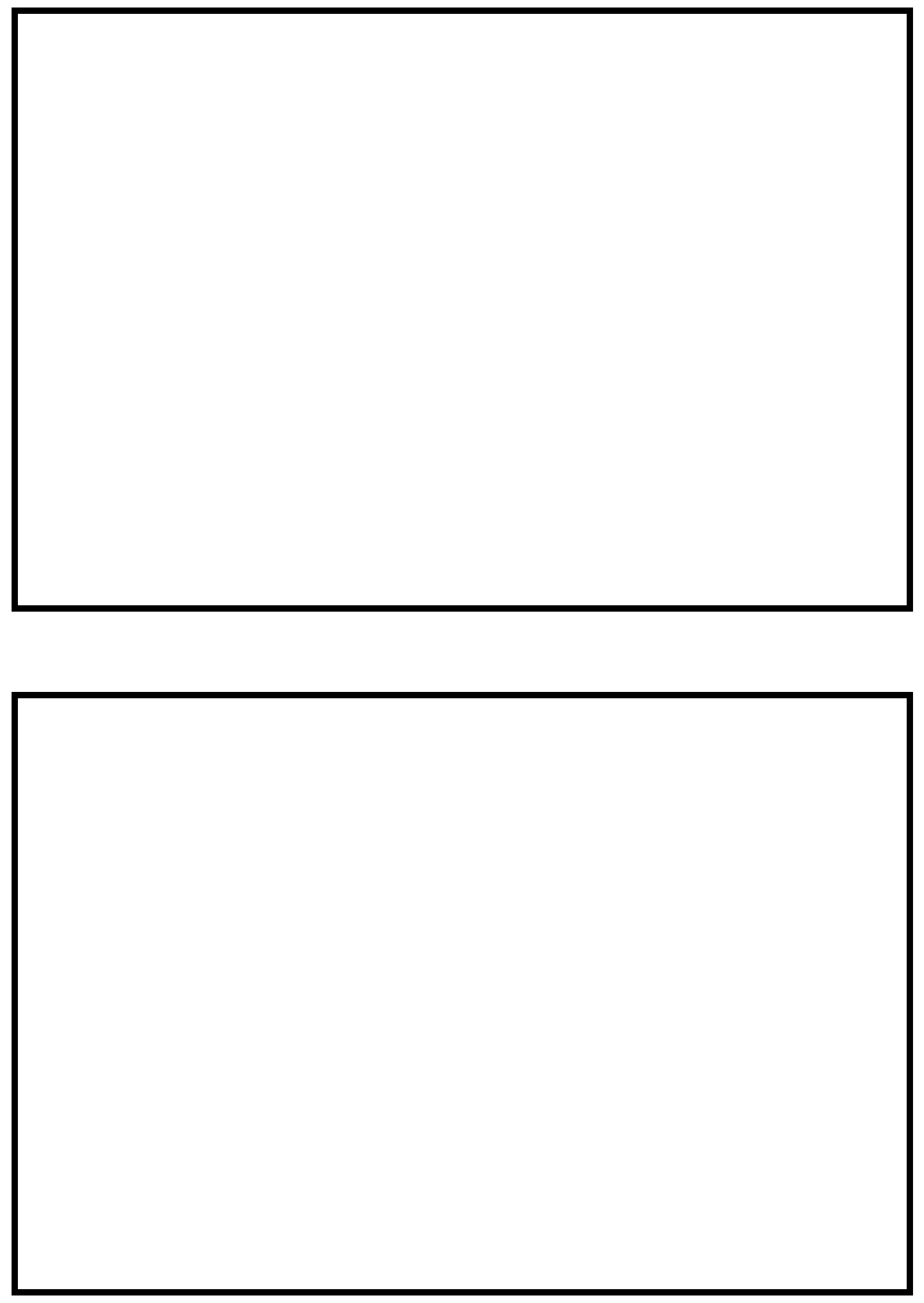

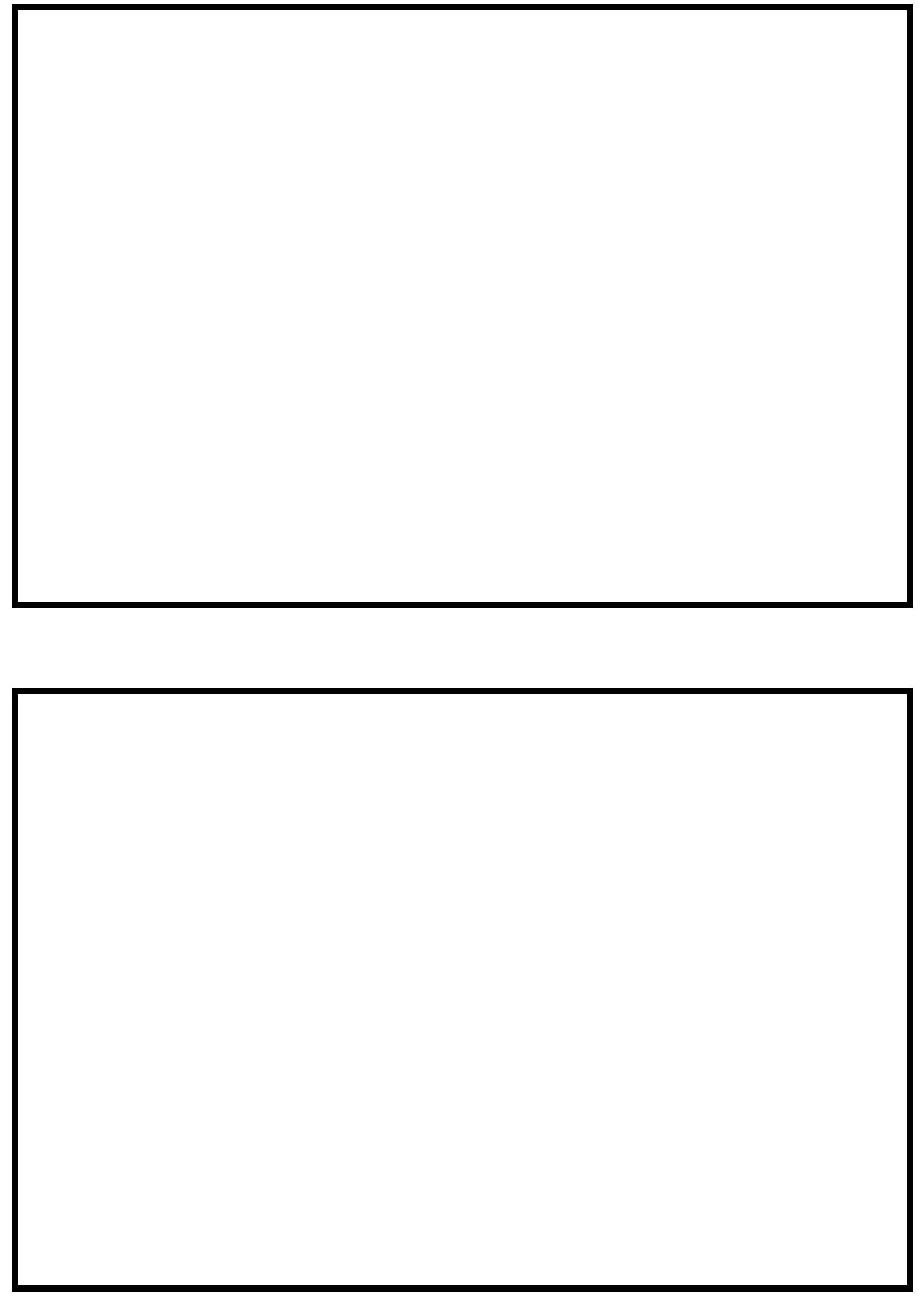


\section{LEVEL II SUMMARY}

\begin{tabular}{llllll} 
Structure Number & \multicolumn{2}{c}{ STJOTH00080027 } & Stream & \multicolumn{2}{c}{ Sleepers River } \\
& Road & TH 8 & District & 7 \\
County & Caledonia & Roann
\end{tabular}

\section{Description of Bridge}

Bridge length $\stackrel{74}{-} \boldsymbol{f t}$ Bridge width $\stackrel{24.0}{f t}$ Max span length $\stackrel{71}{ } \boldsymbol{f t}$ Alignment of bridge to road (on curve or straight)

Abutment type Vertical, concrete

$\begin{array}{lll}\text { Abutment type } & \text { No Embankment type } \\ \text { Stone fill on abutment? } & \text { nato af incnortion }\end{array}$

nam arintion af ato... fill Type-3, around the upstream end of the upstream left wingwall, downstream end of the downstream right wingwall, and DS left bank. Type-2, around the downstream end of the downstream left wingwall, US left bank, and DS right bank.

Abutments and wingwalls are concrete. There is a three to four foot deep scour hole in the channel adjacent to the US right wingwall. A scour hole $2.5 \mathrm{ft}$ deeper than the mean thalweg depth was observed along the right abutment.

Is bridge skewed to flood flow according to $\mathrm{No}^{\text {' survey? }}$

Debris accumulation on bridge at time of Level I or Level II site visit:

\begin{tabular}{|c|c|c|c|}
\hline & $\begin{array}{c}\text { Date af insnortion } \\
8 / 10 / 95 \\
\end{array}$ & $\begin{array}{l}\text { Percent of rhmminal } \\
\text { blocked inortzontatly }\end{array}$ & $\begin{array}{l}\text { Percent of } 0 \\
\text { blocked verticatty }\end{array}$ \\
\hline & $8 / 10 / 95$ & 0 & 0 \\
\hline
\end{tabular}

Level II

Moderate. There is some debris caught on boulders upstream and trees are leaning over the channel upstream along the right bank.

Potential for debris

None, $8 / 10 / 95$.

Dosriho anv, foaturos noar ar at tho hridoo that mav affort flow, (includo ahsorvation dato) 


\section{Description of the Geomorphic Setting}

General topography The channel is located in a moderate relief valley with steep valley walls on both sides.

Geomorphic conditions at bridge site: downstream (DS), upstream (US)

Date of inspection $\quad 8 / 10 / 95$

DS left: $\quad$ Steep channel bank to a narrow overbank.

DS right: $\quad$ Steep channel bank to the flat overbank.

US left: $\quad$ Steep channel bank to a narrow overbank.

US right: $\quad$ Steep valley wall.

\section{Description of the Channel}

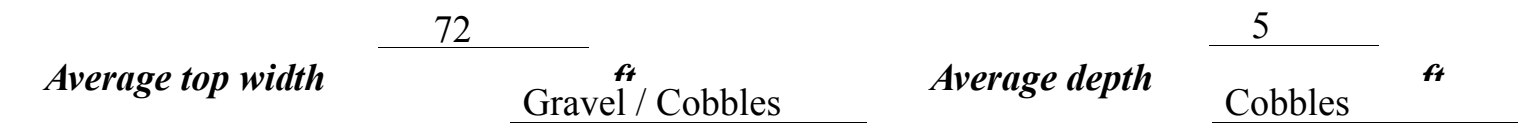

Predominant bed material

Bank material Sinuous but stable

with non-alluvial channel boundaries and no flood plain.

$8 / 10 / 95$

Vegetative co 1 Trees and brush with some pasture.

DS left: $\quad$ Cut grass, some trees, and brush.

DS right: $\quad$ Pasture with trees and brush.

US left: $\quad$ Trees and brush.

US right: $\quad$ Yes

Do banks appear stable? -

y mug, пе

date of observatton.

The assessment of

8/10/95 noted some debris caught on boulders in the channel upstream.

Describe any obstructions in channel and date of observation. 


\title{
Hydrology
}

Drainage area $\stackrel{40.4}{\boldsymbol{m i}^{2}}$

Percentage of drainage area in physiographic provinces: (approximate)

Physiographic province/section New England/New England Upland
Percent of drainage area 100

\begin{abstract}
Is drainage area considered rural or urban?
Rural urbanization:

Describe any significant
\end{abstract}

Yes

Is there a USGS gage on the stream of interest? Sleepers River near St. Johnsbury, VT USGS gage description 01135300

USGS gage number 42.9

Gage drainage area $\quad \mathrm{mi}^{2}$ No

Is there a lake/p -

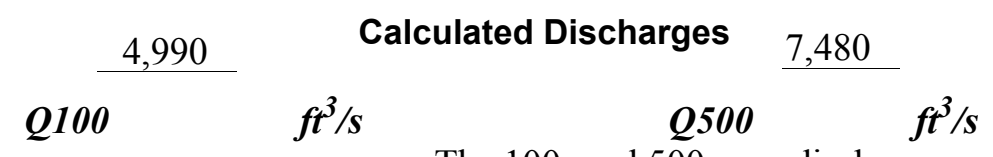

The 100- and 500-year discharges are based on a

drainage area relationship [(40.4/42.9)exp 0.7] with gage 01135300 in St. Johnsbury. The 100and 500- year discharges at the gage were developed using a log-Pearson type-III analysis of annual peak-flow data (Interagency Advisory Committee on Water Data, 1982). These discharge values are within a range of several flood frequency curves based on empirical relationships for this site (Benson, 1962; Johnson and Tasker, 1974; FHWA, 1983; Potter, 1957a\&b; Talbot, 1887). 


\section{Description of the Water-Surface Profile Model (WSPRO) Analysis}

Datum for WSPRO analysis (USGS survey, sea level, VTAOT plans)

USGS survey

Datum tie between USGS survey and VTAOT plans Add $176.0 \mathrm{ft}$ to the USGS arbitrary

survey datum to obtain VTAOT plans' datum and National Geodetic Vertical Datum 29.

Description of reference marks used to determine USGS datum. $\quad$ RM1 is the center of an

old chiseled square on top of the downstream end of the left abutment (elev. $501.22 \mathrm{ft}$, arbitrary

survey datum). RM2 is a chiseled X on top of the upstream end of the right abutment (elev.

$501.16 \mathrm{ft}$, arbitrary survey datum).

\section{Cross-Sections Used in WSPRO Analysis}

\begin{tabular}{|c|c|c|c|}
\hline${ }^{1}$ Cross-section & $\begin{array}{c}\text { Section } \\
\text { Reference } \\
\text { Distance } \\
\text { (SRD) in feet }\end{array}$ & $\begin{array}{c}{ }^{2} \text { Cross-section } \\
\text { development }\end{array}$ & Comments \\
\hline EXIT1 & -235 & 5 & $\begin{array}{l}\text { Downstream Exit section } \\
\text { as surveyed in the Flood } \\
\text { Insurance Study }\end{array}$ \\
\hline EXITX & -60 & 1 & Exit section \\
\hline FULLV & 0 & 2 & $\begin{array}{l}\text { Downstream Full-valley } \\
\text { section (Templated from } \\
\text { EXITX) }\end{array}$ \\
\hline BRIDG & 0 & 5 & $\begin{array}{l}\text { Bridge section as surveyed } \\
\text { in the Flood Insurance } \\
\text { Study }\end{array}$ \\
\hline RDWAY & 18 & 1 & Road Grade section \\
\hline APPRO & 85 & 2 & $\begin{array}{l}\text { Modelled Approach sec- } \\
\text { tion (Templated from } \\
\text { APTEM) }\end{array}$ \\
\hline APTEM & 120 & 1 & $\begin{array}{l}\text { Approach section as sur- } \\
\text { veyed (Used as a tem- } \\
\text { plate) }\end{array}$ \\
\hline
\end{tabular}

${ }^{1}$ For location of cross-sections see plan-view sketch included with Level I field form, Appendix E. For more detail on how cross-sections were developed see WSPRO input file. 


\section{Data and Assumptions Used in WSPRO Model}

Hydraulic analyses of the reach were done by use of the Federal Highway Administration's WSPRO step-backwater computer program (Shearman and others, 1986, and Shearman, 1990). The analyses reported herein reflect conditions existing at the site at the time of the study. Furthermore, in the development of the model it was necessary to assume no accumulation of debris or ice at the site. Results of the hydraulic model are presented in the Bridge Hydraulic Summary, Appendix B, and figure 7.

Channel roughness factors (Manning's " $n$ ") used in the hydraulic model were estimated using field inspections at each cross section following the general guidelines described by Arcement and Schneider (1989). Final adjustments to the values were made during the modelling of the reach. Channel " $n$ " values for the reach ranged from 0.040 to 0.055 , and the overbank "n" value was 0.030 .

The starting water surface elevations at the exit section (EXIT1) were taken from the Flood Insurance Study (FIS) for St. Johnsbury, VT (Federal Emergency Management Agency, 1986). The exit section (EXIT1) $235 \mathrm{ft}$ downstream of the bridge and the downstream bridge section (BRIDG) were also obtained from the survey completed for the Flood Insurance Study.

The surveyed approach section (APTEM) was moved along the approach channel slope $(0.020 \mathrm{ft} / \mathrm{ft})$ to establish the modelled approach section (APPRO), one bridge length upstream of the upstream face as recommended by Shearman and others (1986). This location also provides a consistent method for determining scour variables. 


\section{Bridge Hydraulics Summary}

$\begin{array}{llll}\text { Average bridge embankment elevation } & 501.7 & f t \\ \text { Average low steel elevation } & 498.3 & \boldsymbol{f t}\end{array}$

100-year discharge $\quad 4,990 \quad \mathrm{ft}^{3} / \mathrm{s}$

Water-surface elevation in bridge opening $\quad 498.3 \mathrm{ft}$

Road overtopping? ___ Yes Discharge over road __ 1,689 $\mathrm{ft}^{3} / \mathrm{s}$

\begin{tabular}{llll} 
Area of flow in bridge opening & $420 \quad \boldsymbol{f t}^{2}$ \\
\cline { 2 - 3 } Average velocity in bridge opening & 7.9 & $\mathbf{f t} / \mathrm{s}$
\end{tabular}

$\begin{array}{lll}\text { Maximum WSPRO tube velocity at bridge } & 8.7 \quad \mathrm{ft} / \mathrm{s}\end{array}$

Water-surface elevation at Approach section with bridge 502.9

Water-surface elevation at Approach section without bridge $\quad 501.8$

Amount of backwater caused by bridge

1.1 it

500-year discharge $\quad 7,480 \quad \mathrm{ft}^{3} / \mathrm{s}$

Water-surface elevation in bridge opening

$498.3 \boldsymbol{f t}$

Road overtopping? ___ Yes Discharge over road __ 4,807 $\boldsymbol{f t}^{3} / \mathbf{s}$

Area of flow in bridge opening $\quad 420 \quad \mathrm{ft}^{2}$

Average velocity in bridge opening $6.4 \mathrm{ft} / \mathrm{s}$

Maximum WSPRO tube velocity at bridge 7.1 , s

Water-surface elevation at Approach section with bridge 504.4

Water-surface elevation at Approach section without bridge $\quad 503.8$

Amount of backwater caused by bridge 0.6 , ${ }_{t}$

Incipient overtopping discharge $\quad 3,130 \quad \mathrm{ft}^{3} / \mathrm{s}$

Water-surface elevation in bridge opening $498.3 \quad$ it

Area of flow in bridge opening $\quad 420 \quad \mathrm{ft}^{2}$

Average velocity in bridge opening $\quad 7.4 \quad \mathrm{ft} / \mathrm{s}$

Maximum WSPRO tube velocity at bridge $\quad 8.2 \quad \mathrm{ft} / \mathrm{s}$

Water-surface elevation at Approach section with bridge

Water-surface elevation at Approach section without bridge

500.7

Amount of backwater caused by bridge $\quad 1.1$ it 


\section{Scour Analysis Summary}

\section{Special Conditions or Assumptions Made in Scour Analysis}

Scour depths were computed using the general guidelines described in Hydraulic Engineering Circular 18 (Richardson and others, 1995). Scour depths were calculated assuming an infinite depth of erosive material and a homogeneous particle-size distribution. The results of the 100-year and 500-year discharges scour analysis are presented in tables 1 and 2 and a graph of the scour depths is presented in figure 8 .

At this site, each discharge resulted in submerged orifice flow. Contraction scour at bridges with orifice flow is best estimated by use of the Chang pressure-flow scour equation (oral communication, J. Sterling Jones, October 4, 1996). Thus, contraction scour was computed (Table 1, 2, and Figure 8) by use of the Chang equation (Richardson and others, 1995, p. 145-146).

For comparison, contraction scour also was computed for the discharges resulting in orifice flow by use of the Laursen clear-water contraction scour equation (Richardson and others, 1995, p. 32, equation 20) and the Umbrell pressure-flow equation (Richardson and others, 1995, p. 144). The results are presented in Appendix F.

Abutment scour for the right abutment was computed by use of the Froehlich equation (Richardson and others, 1995, p. 48, equation 28). Variables for the Froehlich equation include the Froude number of the flow approaching the embankments, the length of the embankment blocking flow, and the depth of flow approaching the embankment less any roadway overtopping.

Scour at the left abutment was computed by use of the HIRE equation (Richardson and others, 1995, p. 49, equation 29) because the HIRE equation is recommended when the length to depth ratio of the embankment blocking flow exceeds 25 . The variables used by the HIRE abutment-scour equation are defined the same as those defined for the Froehlich abutment-scour equation. 


\section{Scour Results}

\section{0-yr discharge 500-yr discharge}

Contraction scour:

(Scour depths in feet)

Main channel

Live-bed scour

Clear-water scour

Depth to armoring

Left overbank

Right overbank

Local scour:

Abutment scour

Left abutment

9.2

6.2

Right abutment

Pier scour

Pier 1

Pier 2

Pier 3

\section{Abutments:}

Left abutment

Right abutment

Piers:

Pier 1

Pier 2

8.4

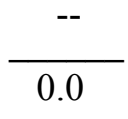

$1.6^{-}$

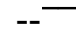

9.7
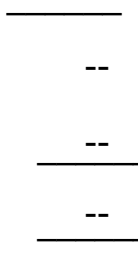

$\longrightarrow$ overtopping discharge
Incipient 


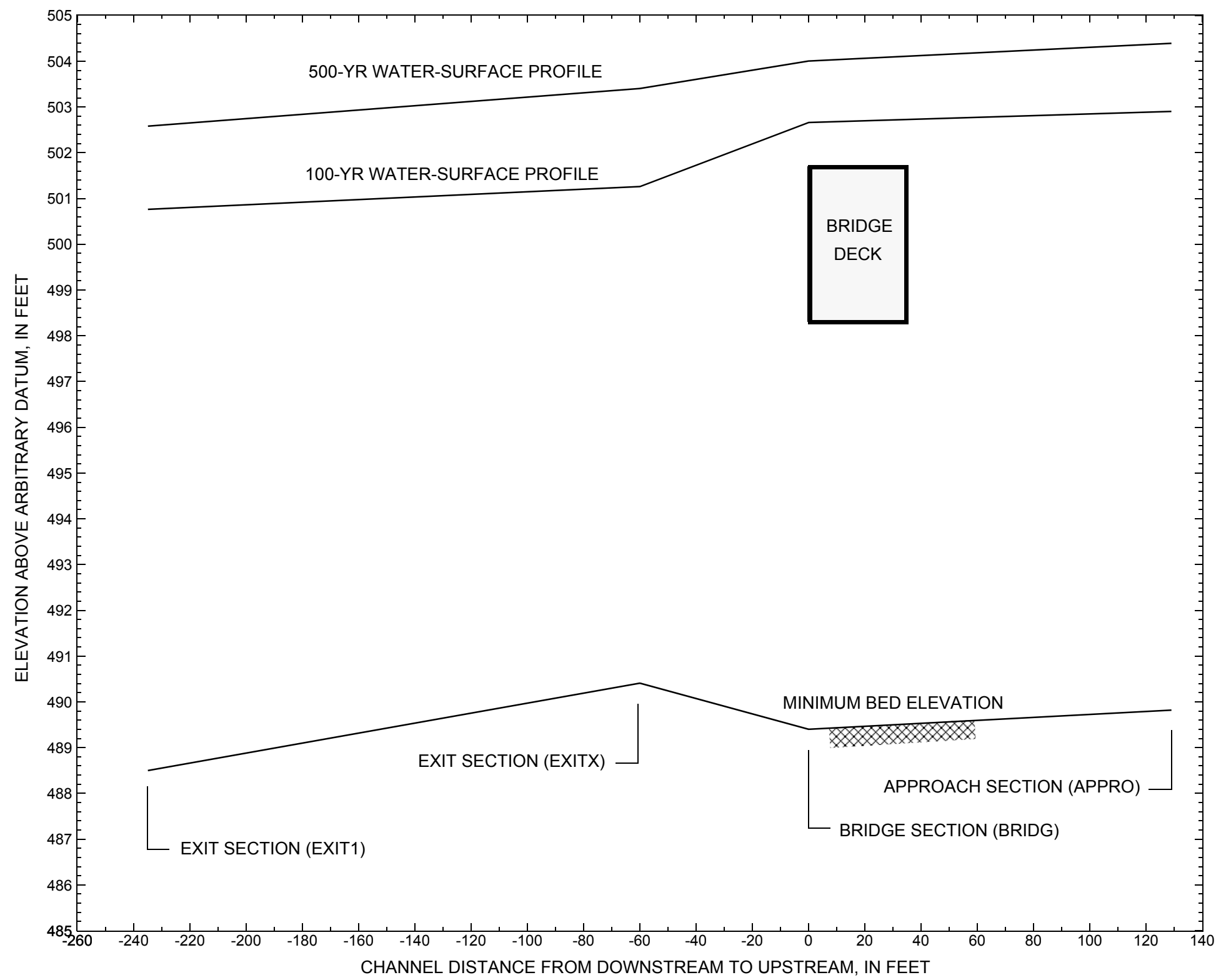

Figure 7. Water-surface profiles for the 100- and 500-yr discharges at structure STJOTH00080027 on Town Highway 8, crossing the Sleepers River, St. Johnsbury, Vermont. 


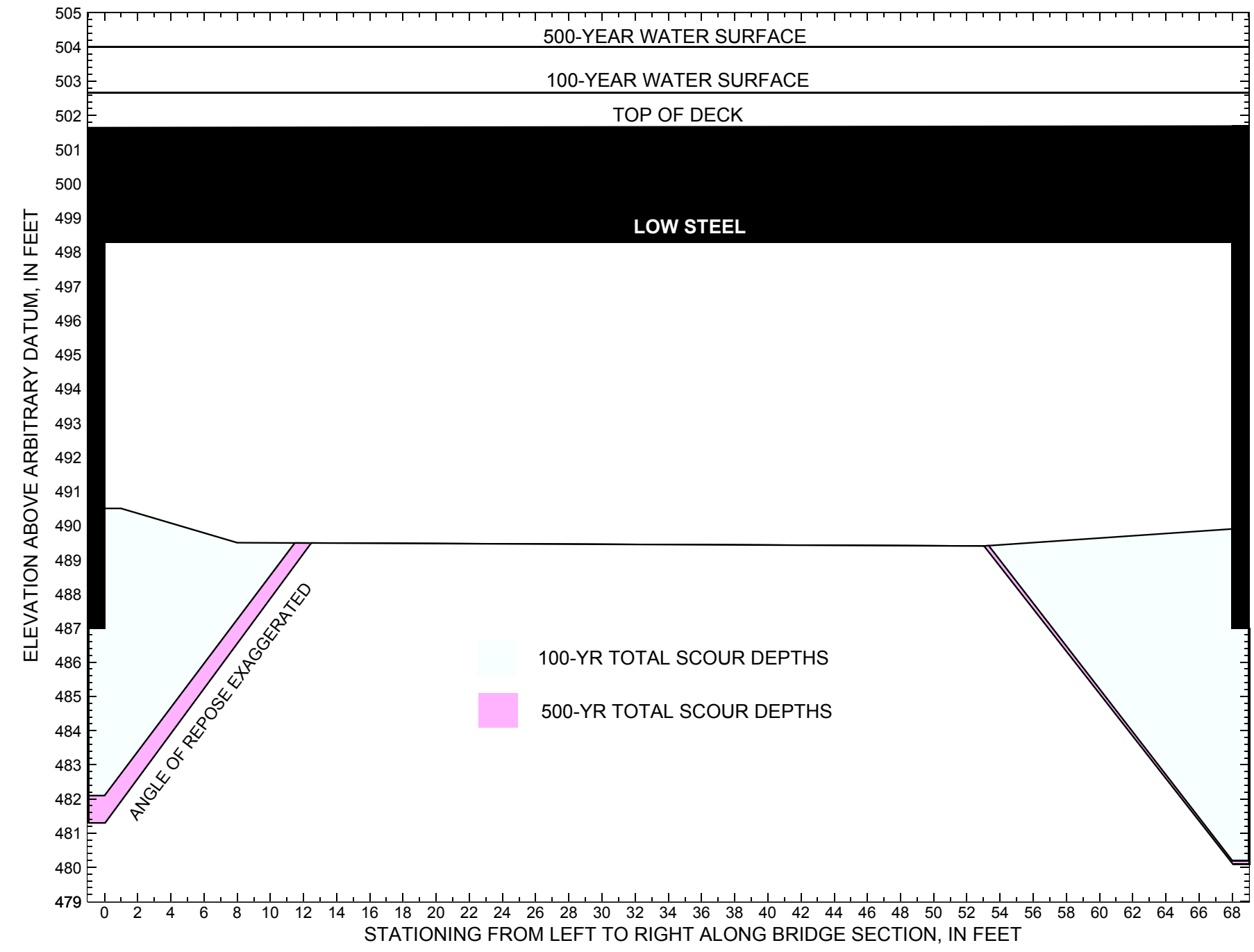

Figure 8. Scour elevations for the 100-yr and 500-yr discharges at structure STJOTH00080027 on Town Highway 8, crossing the Sleepers River, St. Johnsbury, Vermont. 
Table 1. Remaining footing/pile depth at abutments for the 100-year discharge at structure STJOTH00080027 on Town Highway 8 , crossing the Sleepers River, St. Johnsbury, Vermont.

[VTAOT, Vermont Agency of Transportation; --,no data]

\begin{tabular}{|c|c|c|c|c|c|c|c|c|c|c|c|}
\hline Description & Station $^{1}$ & $\begin{array}{c}\text { FEMA } \\
\text { minimum } \\
\text { low steel } \\
\text { elevation } \\
\text { (feet) }\end{array}$ & $\begin{array}{l}\text { Surveyed } \\
\text { minimum } \\
\text { low-chord } \\
\text { elevation }{ }^{2} \\
\text { (feet) }\end{array}$ & $\begin{array}{c}\text { Bottom of } \\
\text { footing/pile } \\
\text { elevation } \\
\text { (feet) }\end{array}$ & $\begin{array}{c}\text { Channel } \\
\text { elevation at } \\
\text { abutment/ } \\
\text { pier }^{2} \\
\text { (feet) }\end{array}$ & $\begin{array}{l}\text { Contraction } \\
\text { scour depth } \\
\text { (feet) }\end{array}$ & $\begin{array}{l}\text { Abutment } \\
\text { scour } \\
\text { depth } \\
\text { (feet) }\end{array}$ & $\begin{array}{l}\text { Pier } \\
\text { scour } \\
\text { depth } \\
\text { (feet) }\end{array}$ & $\begin{array}{l}\text { Depth of } \\
\text { total scour } \\
\text { (feet) }\end{array}$ & $\begin{array}{c}\text { Elevation of } \\
\text { scour }^{2} \\
\text { (feet) }\end{array}$ & $\begin{array}{c}\text { Remaining } \\
\text { footing/pile } \\
\text { depth } \\
\text { (feet) }\end{array}$ \\
\hline \multicolumn{12}{|c|}{100 -yr. discharge is 4,990 cubic-feet per second } \\
\hline Left abutment & 0.0 & 674.3 & 498.3 & 487.0 & 490.5 & 0.0 & 8.4 & -- & 8.4 & 482.1 & -4.9 \\
\hline Right abutment & 68.0 & 674.3 & 498.3 & 487.0 & 489.9 & 0.0 & 9.7 & -- & 9.7 & 480.2 & -6.8 \\
\hline
\end{tabular}

1.Measured along the face of the most constricting side of the bridge.

2.Arbitrary datum for this study.

Table 2. Remaining footing/pile depth at abutments for the 500-year discharge at structure STJOTH00080027 on Town Highway 8, crossing the Sleepers River, St. Johnsbury, Vermont.

[VTAOT, Vermont Agency of Transportation; --, no data]

\begin{tabular}{|c|c|c|c|c|c|c|c|c|c|c|c|}
\hline Description & Station $^{1}$ & $\begin{array}{c}\text { FEMA } \\
\text { minimum } \\
\text { low steel } \\
\text { elevation } \\
\text { (feet) }\end{array}$ & $\begin{array}{c}\text { Surveyed } \\
\text { minimum } \\
\text { low-chord } \\
\text { elevation } \\
\text { (feet) }\end{array}$ & $\begin{array}{c}\text { Bottom of } \\
\text { footing/pile } \\
\text { elevation } \\
\text { (feet) }\end{array}$ & $\begin{array}{c}\text { Channel } \\
\text { elevation at } \\
\text { abutment/ } \\
\text { pier }^{2} \\
\text { (feet) }\end{array}$ & $\begin{array}{l}\text { Contraction } \\
\text { scour depth } \\
\text { (feet) }\end{array}$ & $\begin{array}{c}\text { Abutment } \\
\text { scour } \\
\text { depth } \\
\text { (feet) }\end{array}$ & $\begin{array}{l}\text { Pier } \\
\text { scour } \\
\text { depth } \\
\text { (feet) }\end{array}$ & $\begin{array}{l}\text { Depth of } \\
\text { total scour } \\
\text { (feet) }\end{array}$ & $\begin{array}{c}\text { Elevation of } \\
\text { scour }^{2} \\
\text { (feet) }\end{array}$ & $\begin{array}{c}\text { Remaining } \\
\text { footing/pile } \\
\text { depth } \\
\text { (feet) }\end{array}$ \\
\hline \multicolumn{12}{|c|}{500 -yr. discharge is 7,480 cubic-feet per second } \\
\hline Left abutment & 0.0 & 674.3 & 498.3 & 487.0 & 490.5 & 0.0 & 9.2 & -- & 9.2 & 481.3 & -5.7 \\
\hline Right abutment & 68.0 & 674.3 & 498.3 & 487.0 & 489.9 & 0.0 & 8.9 & -- & 8.9 & 481.0 & -6.0 \\
\hline
\end{tabular}

1.Measured along the face of the most constricting side of the bridge.

2.Arbitrary datum for this study. 


\section{SELECTED REFERENCES}

Arcement, G.J., Jr., and Schneider, V.R., 1989, Guide for selecting Manning's roughness coefficients for natural channels and flood plains:

U.S. Geological Survey Water-Supply Paper 2339, 38 p.

Barnes, H.H., Jr., 1967, Roughness characteristics of natural channels: U.S. Geological Survey Water-Supply Paper 1849,213 p.

Benson, M. A., 1962, Factors Influencing the Occurrence of Floods in a Humid Region of Diverse Terrain: U.S. Geological Survey WaterSupply Paper 1580-B, 64 p.

Brown, S.A. and Clyde, E.S., 1989, Design of riprap revetment: Federal Highway Administration Hydraulic Engineering Circular No. 11, Publication FHWA-IP-89-016, 156 p.

Federal Highway Administration, 1983, Runoff estimates for small watersheds and development of sound design: Federal Highway Administration Report FHWA-RD-77-158.

Federal Highway Administration, 1993, Stream Stability and Scour at Highway Bridges: Participant Workbook: Federal Highway Administration Report FHWA-HI-91-011.

Federal Emergency Management Agency, 1986, Flood Insurance Study, Town of St. Johnsbury, Caledonia County, Vermont: Washington, D.C., July 3, 1986.

Froehlich, D.C., 1989, Local scour at bridge abutments in Ports, M.A., ed., Hydraulic Engineering--Proceedings of the 1989 National Conference on Hydraulic Engineering: New York, American Society of Civil Engineers, p. 13-18.

Hayes, D.C.,1993, Site selection and collection of bridge-scour data in Delaware, Maryland, and Virginia: U.S. Geological Survey WaterResources Investigation Report 93-4017, 23 p.

Interagency Advisory Committee on Water Data, 1982, Guidelines for determining flood flow frequency: U.S. Geological Survey, Bulletin 17B of the Hydrology Subcommittee, 190 p.

Johnson, C.G. and Tasker, G.D.,1974, Progress report on flood magnitude and frequency of Vermont streams: U.S. Geological Survey OpenFile Report 74-130, 37 p.

Lagasse, P.F., Schall, J.D., Johnson, F., Richardson, E.V., Chang, F., 1995, Stream Stability at Highway Structures: Federal Highway Administration Hydraulic Engineering Circular No. 20, Publication FHWA-IP-90-014, 144 p.

Laursen, E.M., 1960, Scour at bridge crossings: Journal of the Hydraulics Division, American Society of Civil Engineers, v. 86, no. HY2, p. 39-53.

Potter, W. D., 1957a, Peak rates of runoff in the Adirondack, White Mountains, and Maine woods area, Bureau of Public Roads

Potter, W. D., 1957b, Peak rates of runoff in the New England Hill and Lowland area, Bureau of Public Roads

Richardson, E.V. and Davis, S.R., 1995, Evaluating scour at bridges: Federal Highway Administration Hydraulic Engineering Circular No. 18, Publication FHWA-IP-90-017, 204 p.

Richardson, E.V., Simons, D.B., and Julien, P.Y., 1990, Highways in the river environment: Federal Highway Administration Publication FHWA-HI-90-016.

Ritter, D.F., 1984, Process Geomorphology: W.C. Brown Co., Debuque, Iowa, 603 p.

Shearman, J.O., 1990, User's manual for WSPRO--a computer model for water surface profile computations: Federal Highway Administration Publication FHWA-IP-89-027, 187 p.

Shearman, J.O., Kirby, W.H., Schneider, V.R., and Flippo, H.N., 1986, Bridge waterways analysis model; research report: Federal Highway Administration Publication FHWA-RD-86-108, 112 p.

Talbot, A.N., 1887, The determination of water-way for bridges and culverts.

U.S. Department of Transportation, 1993, Stream stability and scour at highway bridges, Participant Workbook: Federal Highway Administration Publication FHWA HI-91-011.

U.S. Geological Survey, 1983, St. Johnsbury, Vermont 7.5 X 15 Minute Series quadrangle map: U.S. Geological Survey Topographic Maps, Scale 1:25,000. 


\section{APPENDIX A: \\ WSPRO INPUT FILE}




\section{WSPRO INPUT FILE}

U.S. Geological Survey WSPRO Input File stjo027.wsp Hydraulic analysis for structure STJOTH00080027 Date: 09-JUN-97 Bridge 27 on Town Highway 8 over Sleepers River, St.Johnsbury, VT by MAI 


\section{APPENDIX B: \\ WSPRO OUTPUT FILE}




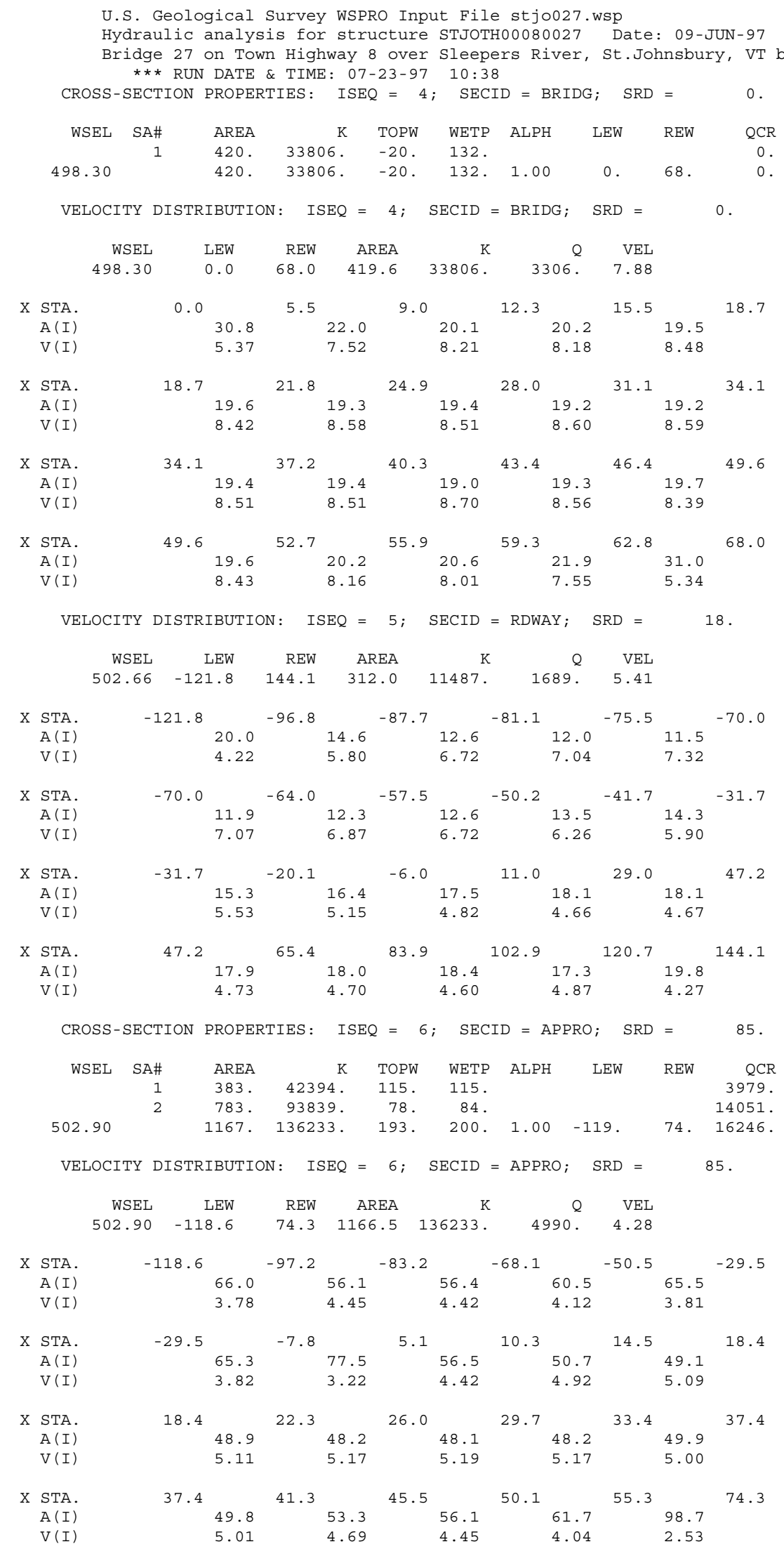


WSPRO OUTPUT FILE (continued)

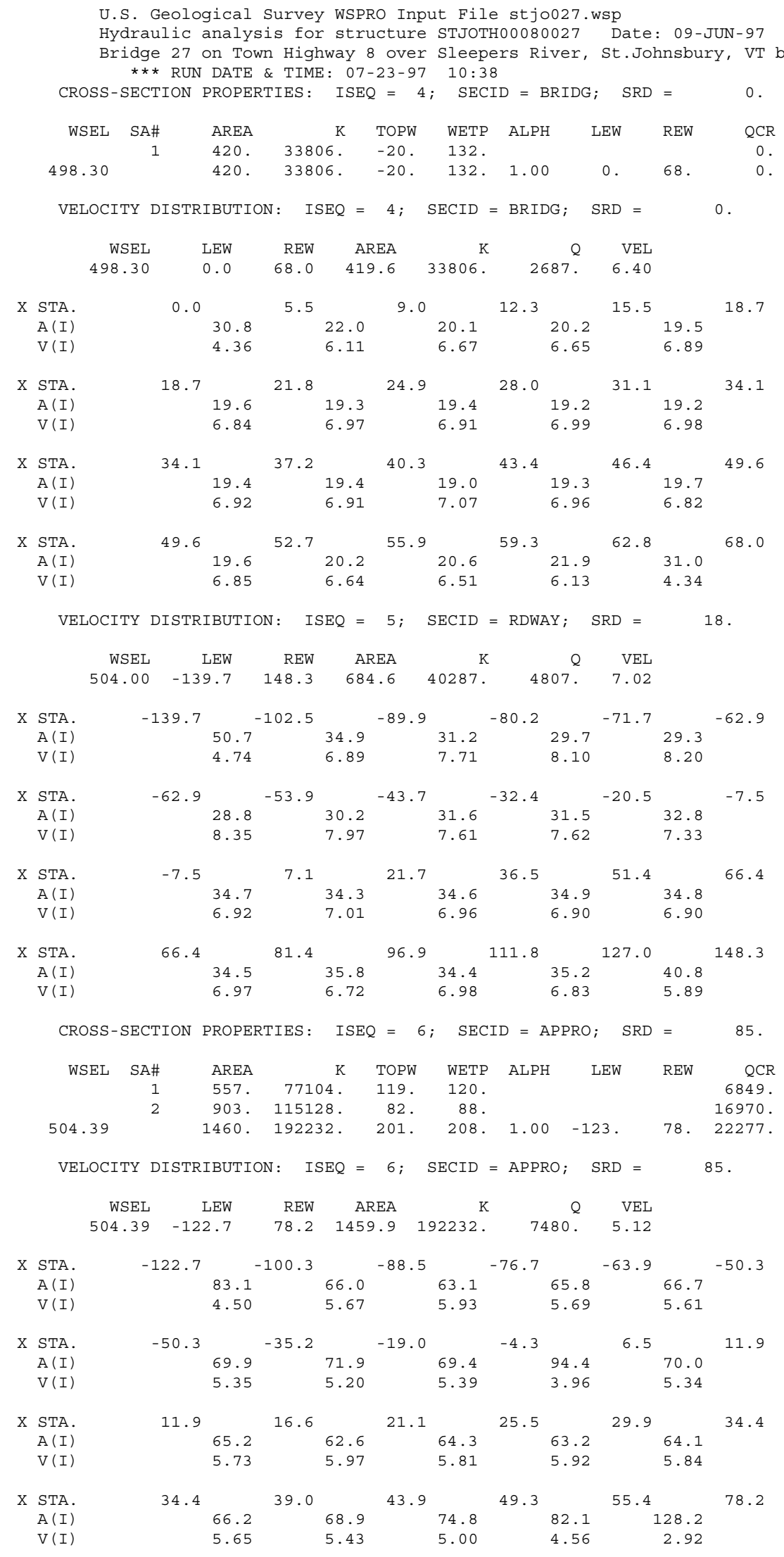


WSPRO OUTPUT FILE (continued)

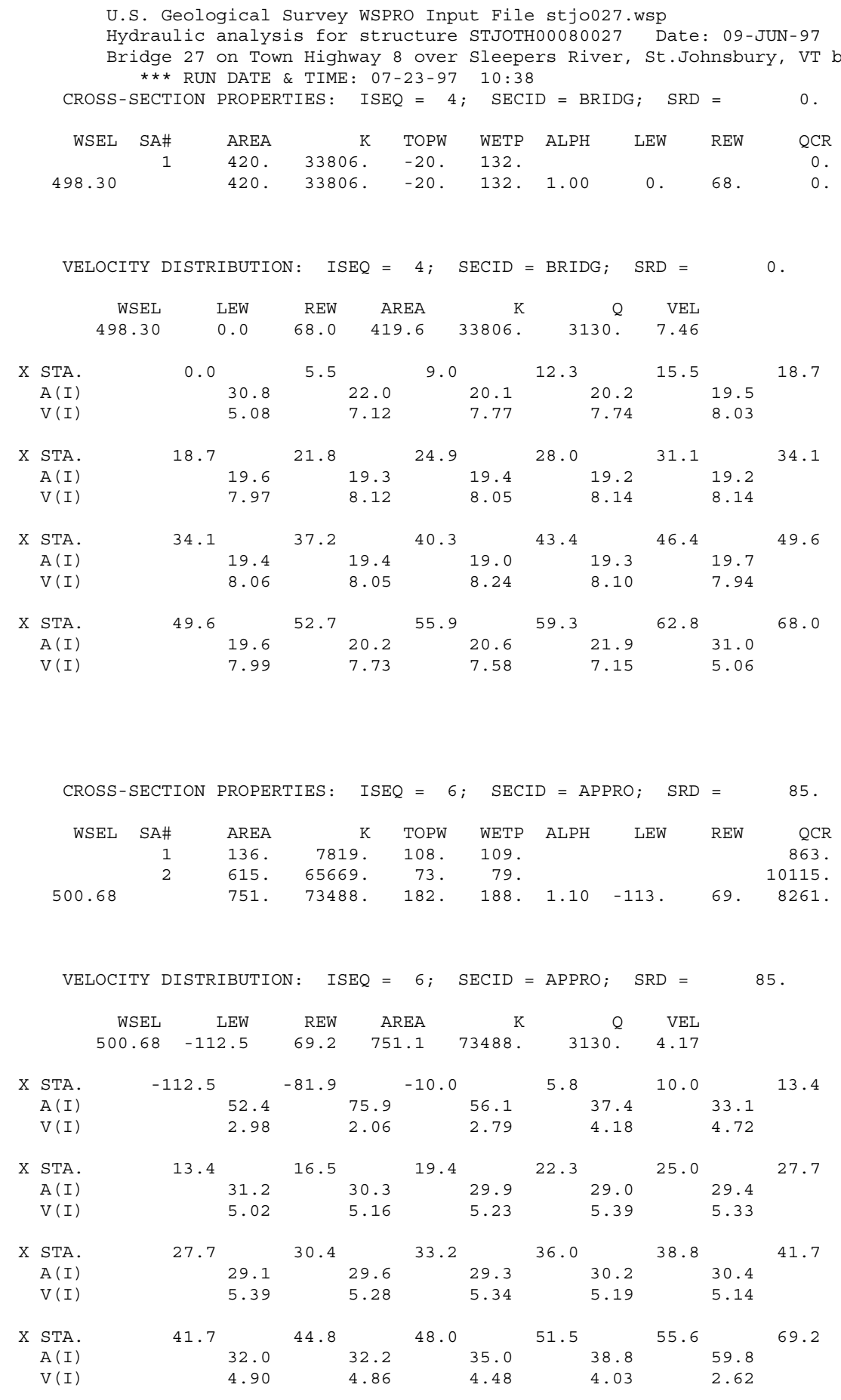


WSPRO OUTPUT FILE (continued)

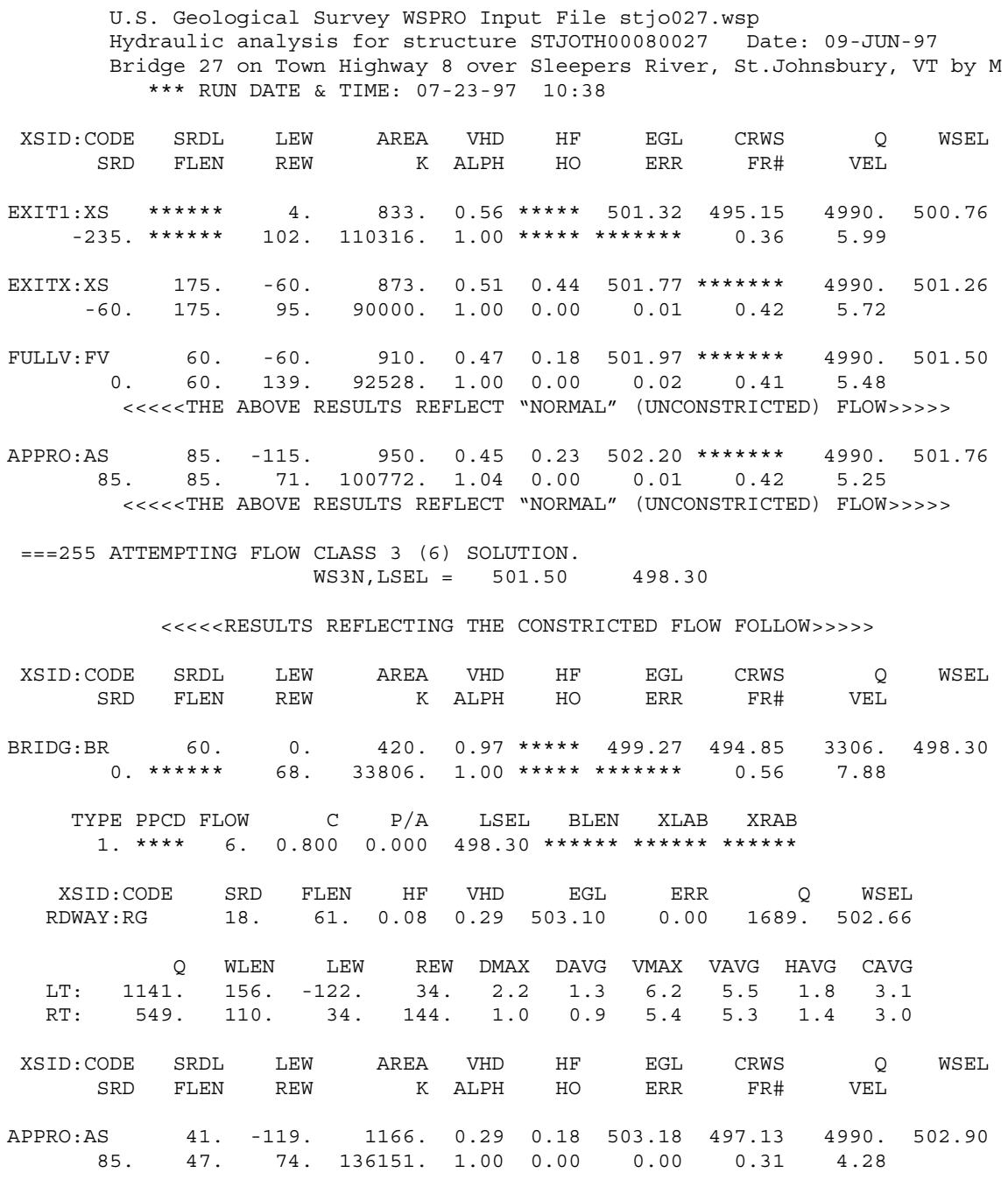

FIRST USER DEFINED TABLE.

$\begin{array}{lrrrrrrrr}\text { XSID : CODE } & \text { SRD } & \text { LEW } & \text { REW } & Q & \text { K } & \text { AREA } & \text { VEL } & \text { WSEL } \\ \text { EXIT1:XS } & -235 . & 4 . & 102 . & 4990 . & 110316 . & 833 . & 5.99 & 500.76 \\ \text { EXITX :XS } & -60 . & -60 . & 95 . & 4990 . & 90000 . & 873 . & 5.72 & 501.26 \\ \text { FULLV :FV } & 0 . & -60 . & 139 . & 4990 . & 92528 . & 910 . & 5.48 & 501.50 \\ \text { BRIDG : BR } & 0 . & 0 . & 68 . & 3306 . & 33806 . & 420 . & 7.88 & 498.30 \\ \text { RDWAY : RG } & 18 . * * * * * * * & 1141 . & 1689 . * * * * * * * * * * * * * * * * & 1.00 & 502.66 \\ \text { APPRO : AS } & 85 . & -119 . & 74 . & 4990 . & 136151 . & 1166 . & 4.28 & 502.90\end{array}$

SECOND USER DEFINED TABLE.

$\begin{array}{lcrrrrrrrr}\text { XSID:CODE } & \text { CRWS } & \text { FR\# } & \text { YMIN } & \text { YMAX } & \text { HF } & \text { HO } & \text { VHD } & \text { EGL } & \text { WSEL } \\ \text { EXIT1:XS } & 495.15 & 0.36 & 488.50 & 507.80 * * * * * * * * * * & 0.56 & 501.32 & 500.76 \\ \text { EXITX:XS } & * * * * * * * * & 0.42 & 490.41 & 513.80 & 0.44 & 0.00 & 0.51 & 501.77 & 501.26 \\ \text { FULLV:FV } & * * * * * * * * & 0.41 & 490.41 & 513.80 & 0.18 & 0.00 & 0.47 & 501.97 & 501.50 \\ \text { BRIDG :BR } & 494.85 & 0.56 & 489.40 & 498.30 * * * * * * * * * * * & 0.97 & 499.27 & 498.30 \\ \text { RDWAY:RG } & * * * * * * * * * * * * * * * & 500.46 & 503.98 & 0.08 * * * * * * & 0.29 & 503.10 & 502.66 \\ \text { APPRO:AS } & 497.13 & 0.31 & 489.82 & 511.04 & 0.18 & 0.00 & 0.29 & 503.18 & 502.90\end{array}$


WSPRO OUTPUT FILE (continued)

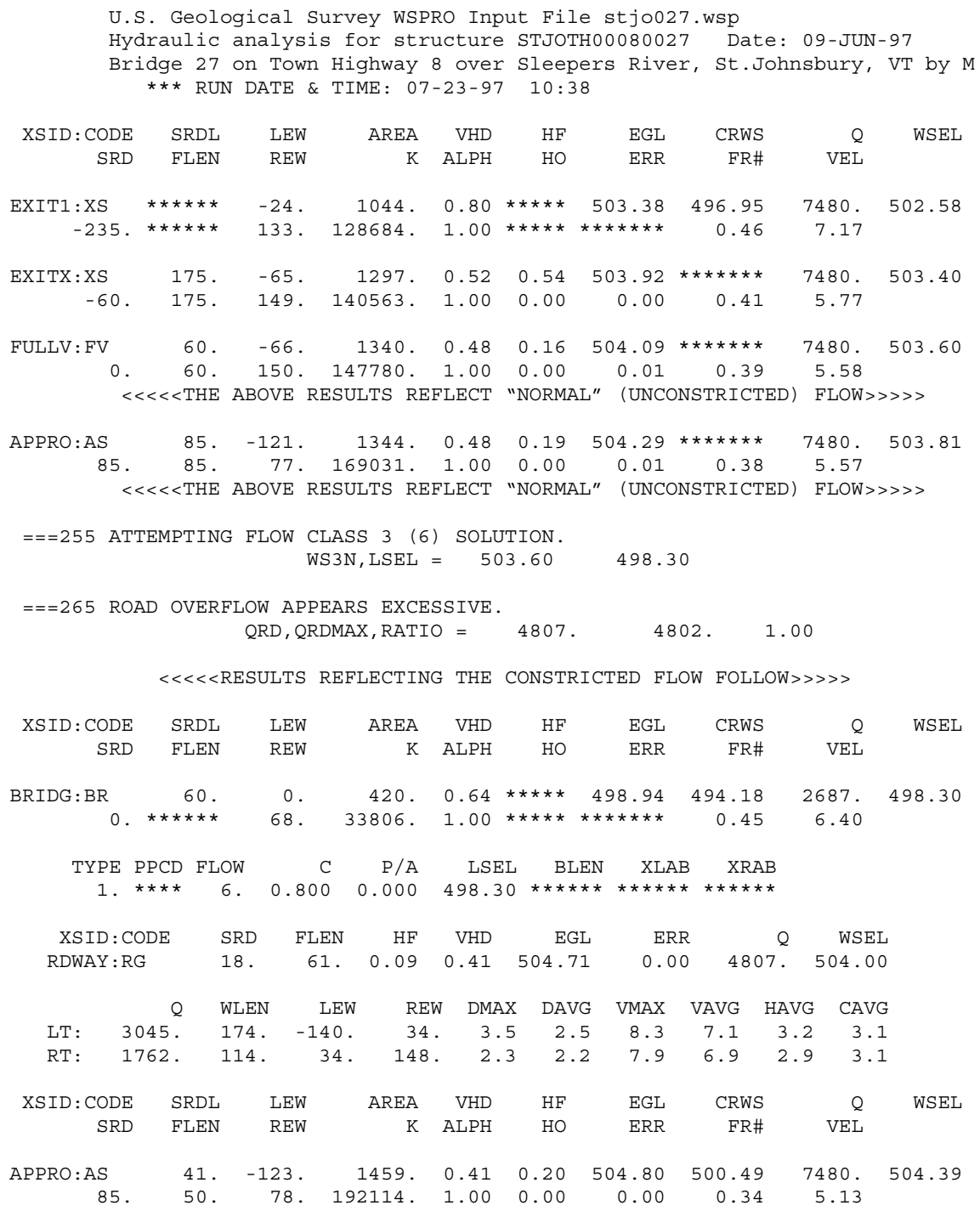

FIRST USER DEFINED TABLE.

\begin{tabular}{|c|c|c|c|c|c|c|c|c|}
\hline XSID : CODE & SRD & LEW & REW & Q & K & AREA & VEL & WSEL \\
\hline EXIT1:XS & -235. & -24 . & 133. & 7480. & 128684 . & 1044 & 7.17 & 502.58 \\
\hline EXITX:XS & -60. & -65 & 149. & 7480. & 140563. & 1297. & 5.77 & 503.40 \\
\hline FULLV : FV & 0 . & -66 & 150. & 7480. & 147780 . & 1340. & 5.58 & 503.60 \\
\hline BRIDG: BR & 0 . & 0 . & 68. & 2687. & 33806 . & 420 & 6.40 & 498.30 \\
\hline RDWAY : RG & 18. * & $\star * \star * *$ & 3045 . & 4807 . & 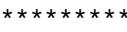 & 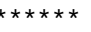 & 1.00 & 504.00 \\
\hline APPRO:AS & 85. & -123. & 78 . & 7480 . & 192114 . & 1459 . & 5.13 & 504.39 \\
\hline
\end{tabular}

SECOND USER DEFINED TABLE.

$\begin{array}{lcrrrrrrrr}\text { XSID : CODE } & \text { CRWS } & \text { FR\# } & \text { YMIN } & \text { YMAX } & \text { HF } & \text { HO } & \text { VHD } & \text { EGL } & \text { WSEL } \\ \text { EXIT1:XS } & 496.95 & 0.46 & 488.50 & 507.80 * * * * * * * * * * * & 0.80 & 503.38 & 502.58 \\ \text { EXITX:XS } & * * * * * * * & 0.41 & 490.41 & 513.80 & 0.54 & 0.00 & 0.52 & 503.92 & 503.40 \\ \text { FULLV:FV } & * * * * * * * * & 0.39 & 490.41 & 513.80 & 0.16 & 0.00 & 0.48 & 504.09 & 503.60 \\ \text { BRIDG:BR } & 494.18 & 0.45 & 489.40 & 498.30 * * * * * * * * * * * & 0.64 & 498.94 & 498.30 \\ \text { RDWAY:RG } & * * * * * * * * * * * * * * * & 500.46 & 503.98 & 0.09 * * * * * * & 0.41 & 504.71 & 504.00 \\ \text { APPRO:AS } & 500.49 & 0.34 & 489.82 & 511.04 & 0.20 & 0.00 & 0.41 & 504.80 & 504.39\end{array}$


WSPRO OUTPUT FILE (continued)

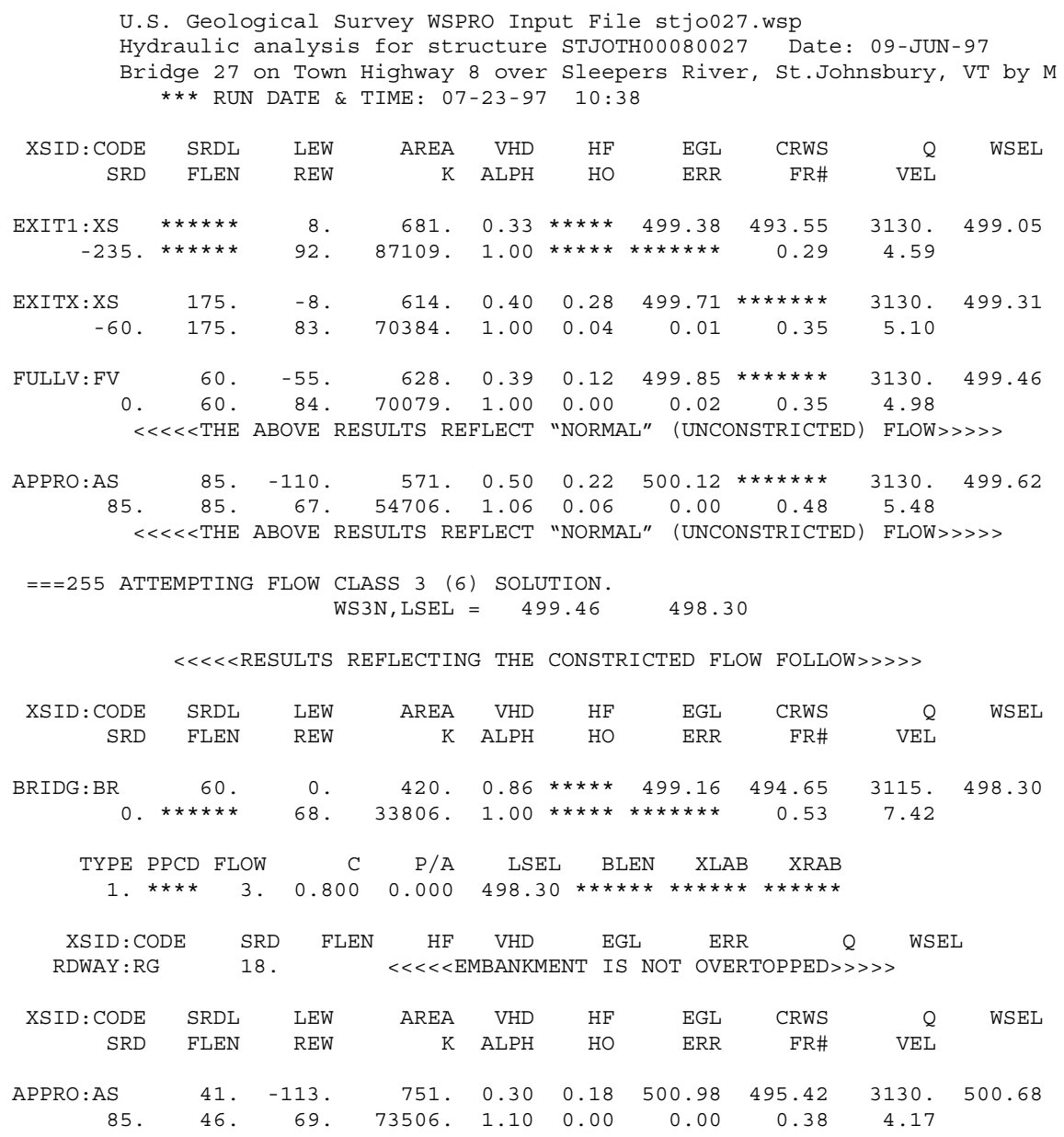

FIRST USER DEFINED TABLE.

\begin{tabular}{lrrrrrrrr} 
XSID : CODE & SRD & LEW & REW & $Q$ & K & AREA & VEL & WSEL \\
EXIT1:XS & -235. & 8. & 92. & 3130. & 87109. & 681. & 4.59 & 499.05 \\
EXITX: XS & -60. & -8. & 83. & 3130. & 70384. & 614. & 5.10 & 499.31 \\
FULLV : FV & 0. & -55. & 84. & 3130. & 70079. & 628. & 4.98 & 499.46 \\
BRIDG : BR & 0. & 0. & 68. & 3115. & 33806. & 420. & 7.42 & 498.30 \\
RDWAY : RG & \multicolumn{2}{c}{$18 . * * * * * * * * * * *$} & 0. & 0. & 0. & $1.00 * * * * * * *$ \\
APPRO: AS & 85. & -113. & 69. & 3130. & 73506. & 751. & 4.17 & 500.68
\end{tabular}

SECOND USER DEFINED TABLE.

$\begin{array}{lrrrrrrrrr}\text { XSID :CODE } & \text { CRWS } & \text { FR\# } & \text { YMIN } & \text { YMAX } & \text { HF } & \text { HO } & \text { VHD } & \text { EGL } & \text { WSEL } \\ \text { EXIT1:XS } & 493.55 & 0.29 & 488.50 & 507.80 * * * * * * * * * * & 0.33 & 499.38 & 499.05 \\ \text { EXITX:XS } & * * * * * * * * & 0.35 & 490.41 & 513.80 & 0.28 & 0.04 & 0.40 & 499.71 & 499.31 \\ \text { FULLV:FV } & * * * * * * * * & 0.35 & 490.41 & 513.80 & 0.12 & 0.00 & 0.39 & 499.85 & 499.46 \\ \text { BRIDG :BR } & 494.65 & 0.53 & 489.40 & 498.30 * * * * * * * * * * & 0.86 & 499.16 & 498.30 \\ \text { RDWAY:RG } & * * * * * * * * * * * * * * * & 500.46 & 503.98 * * * * * * * * * * * & 0.30 & 500.87 * * * * * * * \\ \text { APPRO:AS } & 495.42 & 0.38 & 489.82 & 511.04 & 0.18 & 0.00 & 0.30 & 500.98 & 500.68\end{array}$




\section{APPENDIX C:}

\section{BED-MATERIAL PARTICLE-SIZE DISTRIBUTION}




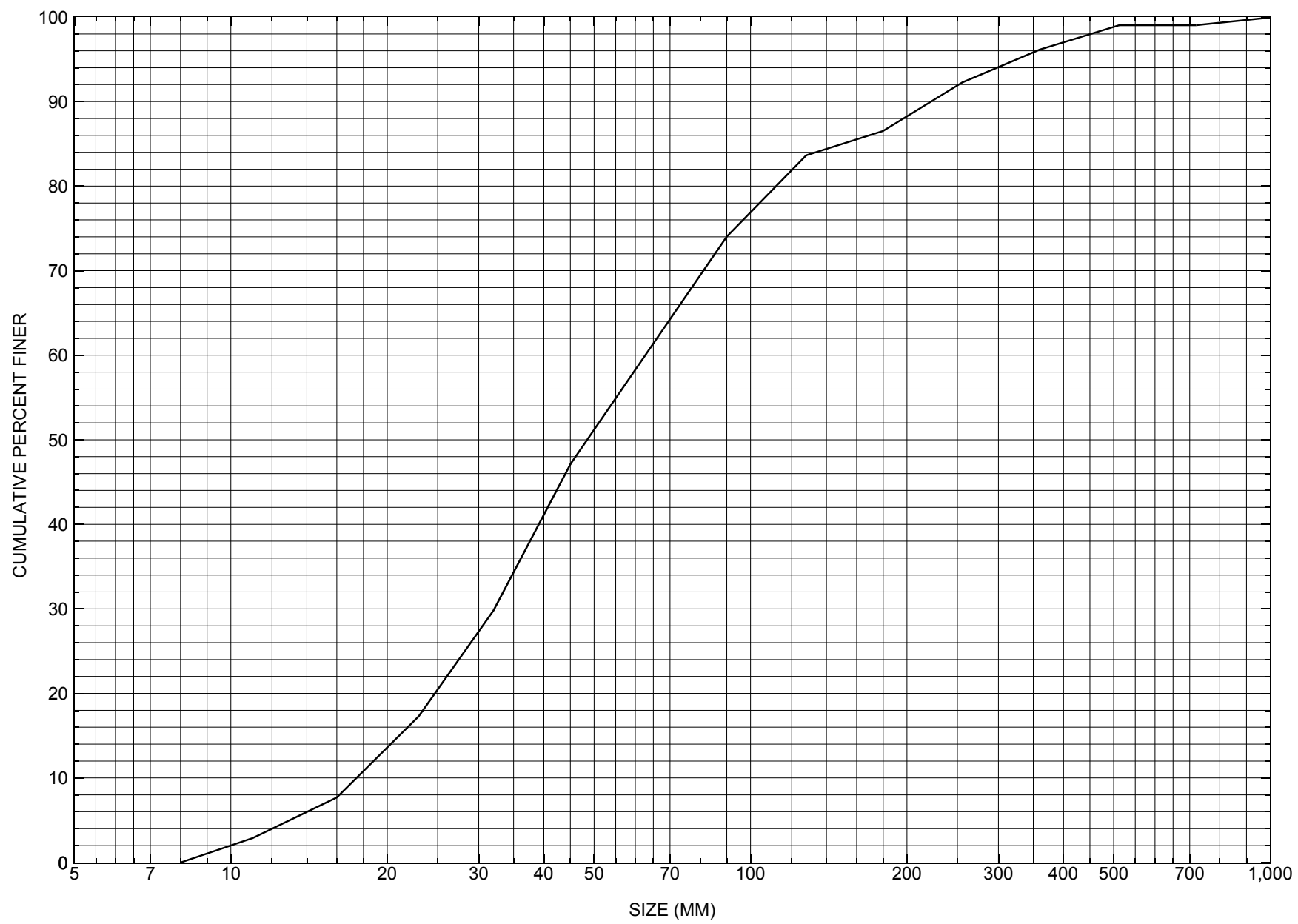

Appendix C. Bed material particle-size distribution for a pebble count in the channel approach of structure STJOTH00080027, in St. Johnsbury, Vermont. 


\section{APPENDIX D: \\ HISTORICAL DATA FORM}




\section{Structure Number STJOTH00080027}

\section{General Location Descriptive}

Data collected by (First Initial, Full last name) $\underline{\mathbf{E}}$. Boehmler

Date $(M M / D D / Y Y) \_\mathbf{0 3} / \underline{\mathbf{2 8}} / \underline{\mathbf{9 5}}$

Highway District Number (I - 2; nn) $\mathbf{0 7}$

Town (FIPS place code; I - 4; nnnnn)

Waterway (I - 6) Sleepers River

Route Number TH008

Topographic Map St.Johnsbury

Latitude (I - 16; nnnn.n) $\mathbf{4 4 2 6 7}$
County (FIPS county code; I - 3; nnn)

Mile marker (I - 11; nnn.nnn) $\mathbf{0 0 0 0 0 0}$

Road Name (I - 7): -

Vicinity (I - 9) At the junction with TH44

Hydrologic Unit Code: $\mathbf{0 1 0 8 0 1 0 2}$

Longitude (i - 17; nnnnn.n) $\mathbf{7 2 0 3 2}$

\section{Select Federal Inventory Codes}

FHWA Structure Number (I - 8) 10031100270311

Maintenance responsibility $(I-21 ; n n) \quad \mathbf{0 3}$

Year built (I - 27; YYYY) 1929

Average daily traffic, ADT (I - 29; nnnnnn) 000500

Year of ADT (I - 30; YY) $\mathbf{9 2}$

Opening skew to Roadway $(I-34 ; n n) \quad \mathbf{3 0}$

Operational status $(I-41 ; X) \quad \mathbf{A}$

Structure type (I - 43; nnn) $\mathbf{3 0 2}$

Approach span structure type $(I-44 ; n n n) \quad \mathbf{0 0 0}$

Number of spans (I - 45; nnn) $\underline{\mathbf{0 0 1}}$

Number of approach spans (I - 46; nnnn) $\mathbf{0 0 0 0}$

Comments:

The structural inspection report of $8 / 22 / 94$ indicates the structure is a steel stringer type bridge with a concrete deck and an asphalt roadway surface. The abutment walls and wingwalls are concrete, which has fine cracks, and small leaks reported overall. The left abutment has two random vertical cracks noted on its face. The channel is reported as having scoured down 3 to 4 feet as the right abutment concrete footing is exposed. While the right abutment footing is exposed, the report indicates there has been no undermining or settling at this point. Some stone fill is reported at the ends of the wingwalls. Point bar development problems are reported as minor. (Continued, page 33) 


\section{Bridge Hydrologic Data}

Is there hydrologic data available? $\underline{\mathbf{N}}$ if No, type ctrl-n $h \quad$ VTAOT Drainage area $\left(m i^{2}\right)$ : -

Terrain character:

Stream character \& type: -

Streambed material:

Discharge Data (cfs):

$$
\begin{aligned}
& Q_{2.33}- \\
& Q_{50}-
\end{aligned}
$$

Record flood date $(M M / D D / Y Y)$ :

Estimated Discharge (cfs): Ice conditions (Heavy, Moderate, Light) : -

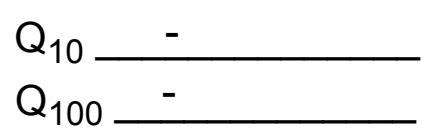

$$
\begin{aligned}
& Q_{25}- \\
& Q_{500}-
\end{aligned}
$$

Water surface elevation $(f t):-$

The stage increases to maximum highwater elevation (Rapidly, Not rapidly):

The stream response is (Flashy, Not flashy):

Describe any significant site conditions upstream or downstream that may influence the stream's stage: -

Watershed storage area (in percent): _ _ \%

The watershed storage area is: - (1-mainly at the headwaters; 2- uniformly distributed; 3-immediatly upstream oi the site)

Water Surface Elevation Estimates for Existing Structure:

\begin{tabular}{|l|l|l|l|l|l|}
\hline Peak discharge frequency & $Q_{2.33}$ & $Q_{10}$ & $Q_{25}$ & $Q_{50}$ & $Q_{100}$ \\
Water surface elevation (ft)) & - & - & - & - & - \\
Velocity (ft/sec) & - & - & - & - & - \\
\hline
\end{tabular}

Long term stream bed changes: -

Is the roadway overtopped below the $\mathrm{Q}_{100}$ ? (Yes, No, Unknown): $\mathbf{U}$ Frequency: Relief Elevation (ft): Discharge over roadway at $Q_{100}\left(f^{3} / \mathrm{sec}\right)$ :

Are there other structures nearby? (Yes, No, Unknown): $\underline{\mathbf{U}}$ Upstream distance (miles): Town: If No or Unknown, type ctrl-n os Highway No. : Structure No. : Year Built:

Clear span (ft): Clear Height $(f t)$ : Full Waterway $\left(f^{2}\right)$ : 
Downstream distance (miles): Town: Year Built:

Highway No. : Structure No. : Structure Type:

Clear span (ft): Clear Height $(f t)$ : Full Waterway $\left(f^{2}\right)$ :

Comments:

Debris accumulation is noted as small piles of brush at the ends of the wingwalls. The foundation type recorded for this bridge is an unknown foundation. The plans show a wooden pile foundation.

\section{USGS Watershed Data}

Watershed Hydrographic Data

Drainage area (DA) $40.38 \mathrm{mi}^{2}$

Watershed storage (ST) 0.23 $\mathrm{mi}^{2}$

Bridge site elevation $676 \quad \mathrm{ft}$ $\%$

Main channel length 7.435 $\mathrm{mi}$

$10 \%$ channel length elevation $\mathbf{7 0 5}$ $\mathrm{ft} \quad 85 \%$ channel length elevation $\mathrm{ft}$

Main channel slope $(S)$

(S) 155.5 $\mathrm{ft} / \mathrm{mi}$

Watershed Precipitation Data

Average site precipitation in Average headwater precipitation in

Maximum 2yr-24hr precipitation event $(124,2)$ in

Average seasonal snowfall (Sn) $\mathrm{ft}$ 


\section{Bridge Plan Data}

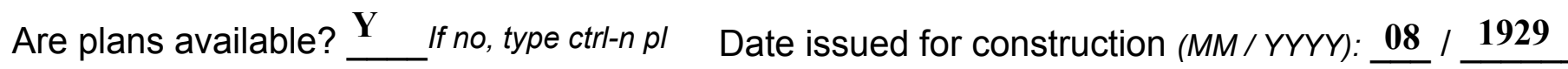

Project Number

Minimum channel bed elevation: 667.0

Low superstructure elevation: USLAB DSLAB USRAB DSRAB -

Benchmark location description:

BM\#2, [spike in root or truck of] a 20 inch elm tree, located about 175 feet right-bankward from the right abutment and about 50 feet perpendicular to the centerline of the roadway toward the downstream right bank of the Sleepers river (on the downstream edge of the old roadway approach to the right abutment of the original structure, elevation 678.10 .

Reference Point (MSL, Arbitrary, Other): MSL Datum (NAD27, NAD83, Other): NGVD1929 Foundation Type: 1 (1-Spreadfooting; 2-Pile; 3- Gravity; 4-Unknown)

If 1 : Footing Thickness $\mathbf{2 . 0} \quad$ Footing bottom elevation: $\underline{\mathbf{6 6 3 . 0}}$

If 2: Pile Type: ___ (1-Wood; 2-Steel or metal; 3-Concrete) Approximate pile driven length: -

If 3: Footing bottom elevation: -

Is boring information available? $\mathbf{N}$ If no, type ctrl-n bi Number of borings taken:

Foundation Material Type: $\mathbf{3}$ (1-regolith, 2-bedrock, 3-unknown)

Briefly describe material at foundation bottom elevation or around piles:

-

Comments:

A high water elevation is shown on plans for the Flood of Nov. 1927, elevation 674.1 


\section{Cross-sectional Data}

Is cross-sectional data available? $\underline{\mathbf{Y}}$ If no, type ctrl-n xs

Source (FEMA, VTAOT, Other)? FEMA

Comments: This cross-section is the downstream face.

\begin{tabular}{|l|l|l|l|l|l|l|l|l|l|l|l|}
\hline Station & 1297 & 1297 & 1305 & 1350 & 1365 & 1369 & - & - & - & - & - \\
\hline Feature & LAB & - & - & - & & RAB & - & - & - & - & - \\
\hline $\begin{array}{l}\text { Low chord } \\
\text { elevation }\end{array}$ & 674.3 & 674.3 & 674.3 & 674.3 & 674.3 & 674.3 & - & - & - & - & - \\
\hline $\begin{array}{l}\text { Bed } \\
\text { elevation }\end{array}$ & 667.5 & 666.5 & 665.5 & 665.4 & 665.9 & 665.9 & - & - & - & - & - \\
\hline $\begin{array}{l}\text { Low chord- } \\
\text { bed }\end{array}$ & 6.8 & 7.8 & 8.8 & 8.9 & 8.4 & 8.4 & - & - & - & - & - \\
\hline Station & - & - & - & - & - & - & - & - & - & - & - \\
\hline Feature & - & - & - & - & - & - & - & - & - & - & - \\
\hline $\begin{array}{l}\text { Low chord } \\
\text { elevation }\end{array}$ & - & - & - & - & - & - & - & - & - & - & - \\
\hline $\begin{array}{l}\text { Bed } \\
\text { elevation }\end{array}$ & - & - & - & - & - & - & - & - & - & - & - \\
\hline $\begin{array}{l}\text { Low chord- } \\
\text { bed }\end{array}$ & - & - & - & - & - & - & - & - & - & - & - \\
\hline
\end{tabular}

Source (FEMA, VTAOT, Other)?

Comments:

\begin{tabular}{|l|l|l|l|l|l|l|l|l|l|l|l|}
\hline Station & - & - & - & - & - & - & - & - & - & - & - \\
\hline Feature & - & - & - & - & - & - & - & - & - & - & - \\
\hline $\begin{array}{l}\text { Low chord } \\
\text { elevation }\end{array}$ & - & - & - & - & - & - & - & - & - & - & - \\
\hline $\begin{array}{l}\text { Bed } \\
\text { elevation }\end{array}$ & - & - & - & - & - & - & - & - & - & - & - \\
\hline $\begin{array}{l}\text { Low chord- } \\
\text { bed }\end{array}$ & - & - & - & - & - & - & - & - & - & - & - \\
\hline Station & - & - & - & - & - & - & - & - & - & - & - \\
\hline Feature & - & - & - & - & - & - & - & - & - & - & - \\
\hline $\begin{array}{l}\text { Low chord } \\
\text { elevation }\end{array}$ & - & - & - & - & - & - & - & - & - & - & - \\
\hline $\begin{array}{l}\text { Bed } \\
\text { elevation }\end{array}$ & - & - & - & - & - & - & - & - & - & - & - \\
\hline $\begin{array}{l}\text { Low chord- } \\
\text { bed }\end{array}$ & - & - & - & - & - & - & - & - & - & - & - \\
\hline
\end{tabular}




\section{APPENDIX E: \\ LEVEL I DATA FORM}


U. S. Geological Survey

Bridge Field Data Collection and Processing Form

Qa/Qc Check by: EW

Date: $\mathbf{0 3 / 2 1 / 9 6}$

\section{Structure Number}

STJOTH00080027

\section{A. General Location Descriptive}

1. Data collected by (First Initial, Full last name) M. IVANOFF

Date $(M M / D D / Y Y) \mathbf{0 8} / \underline{10} / \underline{1995}$

2. Highway District Number 07

County CALENDONIA 005

Waterway (I - 6) SLEEPERS RIVER

Route Number TH08

Mile marker -

Town ST. JOHNSBURY $\mathbf{6 2 2 0 0}$

Road Name -

Hydrologic Unit Code: $\mathbf{0 1 0 8 0 1 0 2}$

3. Descriptive comments:

The site is located at the junction with town highway 44 .

\section{B. Bridge Deck Observations}
4. Surface cover... LBUS 4
RBUS 6
LBDS 6
RBDS 4
Overall 6

(2b us,ds,lb,rb: 1- Urban; 2- Suburban; 3- Row crops; 4- Pasture; 5- Shrub- and brushland; 6- Forest; 7- Wetland)
5. Ambient water surface... US 2
UB 1
DS 2
(1- pool; 2- riffle)

6. Bridge structure type 1 (1- single span; 2- multiple span; 3- single arch; 4- multiple arch; 5-cylindrical culvert; 6- box culvert; or 7- other)

7. Bridge length $\mathbf{7 4}$

(feet)

Span length $\mathbf{7 1}$

(feet)

Bridge width 24

(feet)

\section{Road approach to bridge:}
8. LB 0 RB 0
( 0 even, 1- lower, 2- higher)
9. LB
RB 1
(1-Paved, 2- Not paved)

10. Embankment slope (run / rise in feet / foot)

US left

US right

\begin{tabular}{|c|c|c|c|}
\hline \multicolumn{2}{|c|}{ Protection } & \multirow{2}{*}{ 13.Erosion } & 14.Severity \\
\cline { 6 - 6 } & 12.Cond. & & \\
\hline $\mathbf{3}$ & $\mathbf{1}$ & $\mathbf{0}$ & - \\
\hline
\end{tabular}

LBUS

RBUS

RBDS

LBDS

\begin{tabular}{l|l|l|l}
3 & 1 & 0 & - \\
\hline $\mathbf{0}$ & - & $\mathbf{0}$ & - \\
\hline $\mathbf{2}$ & $\mathbf{1}$ & $\mathbf{0}$ & - \\
\hline $\mathbf{1}$ & $\mathbf{0}$ & - \\
\hline
\end{tabular}

Bank protection types: 0- none; 1- < 12 inches;

2- $<36$ inches; $3-<48$ inches;

4- < 60 inches; 5- wall / artificial levee

Bank protection conditions: 1- good; 2- slumped;

3- eroded; 4- failed

Erosion: 0 - none; 1- channel erosion; 2 -

road wash; 3- both; 4- other

Erosion Severity: 0 - none; 1- slight; 2- moderate; 3- severe

\section{Channel approach to bridge (BF):}

15. Angle of approach: $\mathbf{0}$

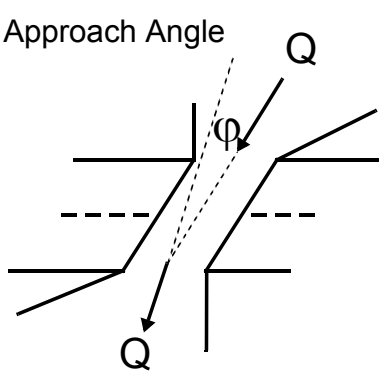

17. Channel impact zone 1 :

Where? RB (LB, RB)

Range? $\mathbf{3 0}$ feet US

Channel impact zone 2:

Where? _ _ $(L B, R B)$

Range? - $\quad$ feet -

(US, UB, DS) to Impact Severity: 0- none to very slight; 1- Slight; 2- Moderate; 3- Severe feet -

16. Bridge skew: $\mathbf{5 0}$ Bridge Skew Angle

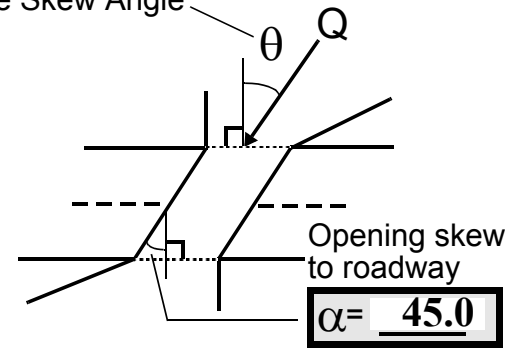

\section{Exist? $\mathbf{Y}(Y$ or $N)$}

Severity 1

US, UB, DS) to $\underline{\mathbf{5}}$ feet $\underline{\mathbf{D S}}$

Exist? $\mathbf{N}(Y$ or $N)$

Severity - 
18. Bridge Type: 1a

1a- Vertical abutments with wingwalls

$1 \mathrm{~b}$ - Vertical abutments without wingwalls

2- Vertical abutments and wingwalls, sloping embankment

Wingwalls parallel to abut. face

3- Spill through abutments

4- Sloping embankment, vertical wingwalls and abutments

Wingwall angle less than $90^{\circ}$.

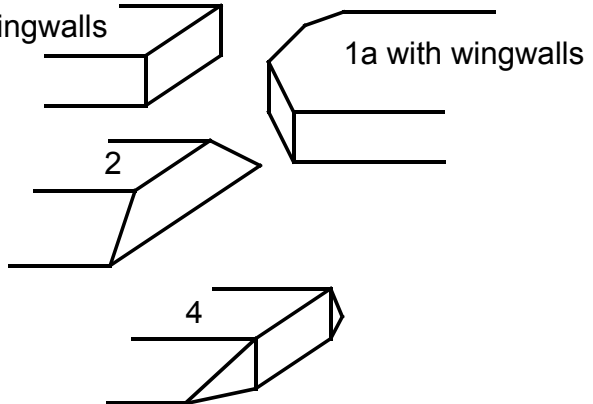

19. Bridge Deck Comments (surface cover variations, measured bridge and span lengths, bridge type variations, approach overflow width, etc.)

\#4: The surface cover on the upstream left bank consists of a road embankment, paved town highway 44, a house with a lawn, and forest. On the downstream left bank there are trees, route 2 and forest area. The downstream right bank has trees along the immediate bank and a house with a lawn. The upstream right bank is forest.

\#11: The protection on the downstream left bank is for town highway 44.

\section{Upstream Channel Assessment}

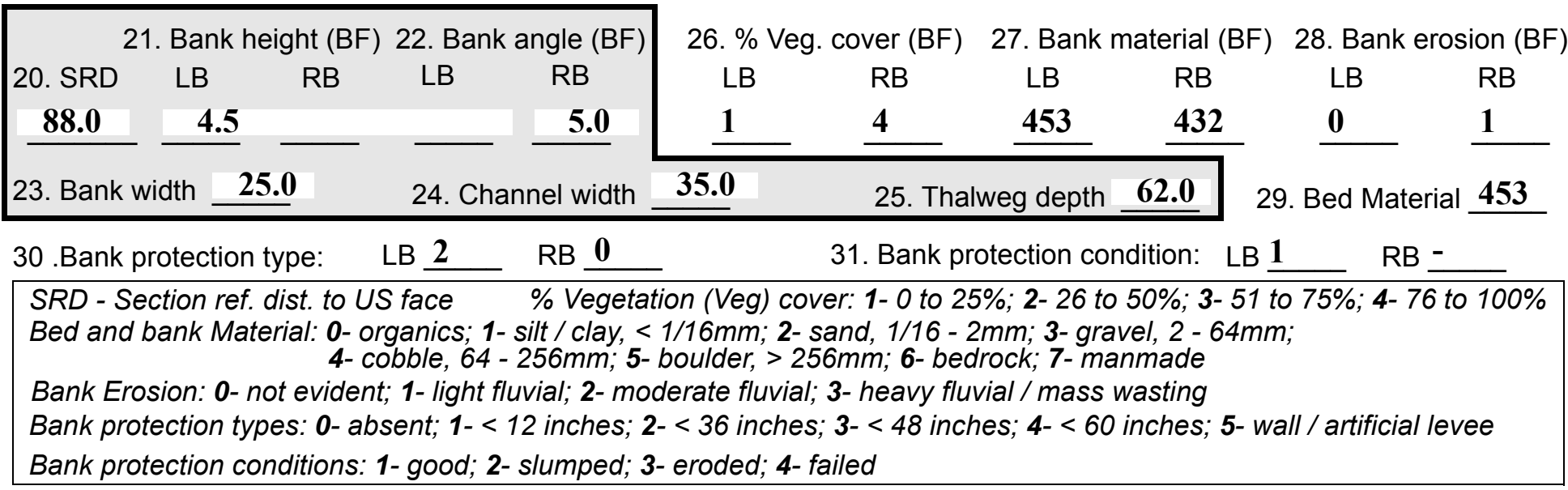

32. Comments (bank material variation, minor inflows, protection extent, etc.):

The left bank material is the embankment for town highway 44 with cobbles, boulders, and gravel. The right bank consists of cobbles, gravel and sand.

The bed material is cobbles, boulders and gravel

The left bank protection extends from 105 feet US to the US end of the junction between the left abutment and wingwall. 
33.Point/Side bar present? $\mathbf{N}(Y$ or $N$. if $N$ type ctrl-n pb)34. Mid-bar distance: -

35. Mid-bar width: -

36. Point bar extent: feet (US, UB) to feet (US, UB, DS) positioned $\%$ LB to $\% \mathrm{RB}$

37. Material: -

38. Point or side bar comments (Circle Point or Side; Note additional bars, material variation, status, etc.):

NO POINT BARS

39. Is a cut-bank present? $\mathbf{N}$ (Y or if $N$ type ctrl-n cb)

40. Where? (LB or $R B)$

41. Mid-bank distance: -

42. Cut bank extent: feet (US, UB) to feet (US, UB, DS)

43. Bank damage: (1- eroded and/or creep; 2- slip failure; 3- block failure)

44. Cut bank comments (eg. additional cut banks, protection condition, etc.):

NO CUT BANKS

\section{Is channel scour present? $\mathbf{Y}$ ( $Y$ or if $N$ type ctrl-n cs)}

46. Mid-scour distance: 10

47. Scour dimensions: Length $\mathbf{1 6 0}$

Width 60 Depth : 4

Position 0 $\%$ LB to $\underline{100} \%$ RB

48. Scour comments (eg. additional scour areas, local scouring process, etc.):

The maximum scour depth is 4.5 feet located 10 feet US from the bridge face.

At the US bridge face there is 3.5 feet of scour.

The US scour extent is from the bridge face to 70 feet US.

\section{Are there major confluences? $\mathbf{N}$}

51. Confluence 1: Distance Confluence 2: Distance 52. Enters on Enters on 54. Confluence comments (eg. confluence name):

\section{NO MAJOR CONFLUENCES}

50. How many? -

53. Type(1- perennial; 2- ephemeral)

Type (1- perennial; 2- ephemeral)

\section{Under Bridge Channel Assessment}

55. Channel restraint (BF)? LB 2

\begin{tabular}{|ccccc|}
\hline \multicolumn{2}{|c|}{ 56. Height (BF) } & \multicolumn{3}{c|}{57 Angle (BF) } \\
LB & RB & LB & RB \\
$\mathbf{4 7 . 0}$ & & & $\mathbf{1 . 0}$ & \\
\hline
\end{tabular}

58. Bank width (BF) (1- natural bank; 2- abutment; 3- artificial levee)

Bed and bank Material: 0- organics; 1- silt / clay, < 1/16mm; 2- sand, 1/16 - 2mm; 3- gravel, 2 - 64mm; 4- cobble, 64 - 256mm; 5- boulder, > 256mm; 6- bedrock; 7- manmade

\begin{tabular}{|c|c|c|}
\hline \multicolumn{2}{|c|}{ 61. Material (BF) } & 62. Erosion (BF) \\
\hline LB & RB & LB \\
\hline 2 & 7 & 7 \\
\hline
\end{tabular}

60. Thalweg depth $\lcm{90.0}$

63. Bed Material -

Bank Erosion: 0- not evident; 1- light fluvial; 2- moderate fluvial; 3- heavy fluvial / mass wasting

64. Comments (bank material variation, minor inflows, protection extent, etc.):

453 
65. Debris and Ice Is there debris accumulation?

(Yor $N)$ 66. Where? $\underline{Y}$

(1- Upstream; 2- At bridge; 3- Both)

67. Debris Potential 1 (1-Low; 2-Moderate; 3- High)

68. Capture Efficiency 2

(1-Low; 2- Moderate; 3- High)

69. Is there evidence of ice build-up? 1 ( $Y$ or $N)$

Ice Blockage Potential $\mathbf{N}$

(1- Low; 2- Moderate; 3- High)

70. Debris and Ice Comments:

1

A $\log$ exists in the channel along the right bank. Trees on the right bank lean toward the channel.

\begin{tabular}{|l|c|c|c|c|c|c|c|c|}
\hline Abutments & $\begin{array}{c}\text { 71. Attack } \\
\angle \text { (BF) }\end{array}$ & $\begin{array}{c}\text { 72. Slope } \angle \\
\text { (Qmax) }\end{array}$ & $\begin{array}{c}\text { 73. Toe } \\
\text { loc. (BF) }\end{array}$ & $\begin{array}{c}\text { 74. Scour } \\
\text { Condition }\end{array}$ & $\begin{array}{c}75 . \text { Scour } \\
\text { depth }\end{array}$ & $\begin{array}{c}\text { 76. Exposure } \\
\text { depth }\end{array}$ & 77. Material & 78. Length \\
\hline LABUT & & $\mathbf{0}$ & $\mathbf{9 0}$ & $\mathbf{2}$ & $\mathbf{1}$ & $\mathbf{0 . 5}$ & $\mathbf{0}$ & $\mathbf{9 0 . 0}$ \\
\hline RABUT & $\mathbf{1}$ & $\mathbf{2 0}$ & $\mathbf{9 0}$ & & & $\mathbf{2}$ & $\mathbf{2}$ & $\mathbf{4 9 . 5}$ \\
\hline
\end{tabular}

Pushed: $L B$ or RB

Toe Location (Loc.): 0- even, 1- set back, 2- protrudes

Scour cond.: 0- not evident; 1- evident (comment); 2- footing exposed; 3-undermined footing; 4- piling exposed; 5- settled; 6- failed

Materials: 1- Concrete; 2- Stone masonry or drywall; 3- steel or metal; 4- wood

79. Abutment comments (eg. undermined penetration, unusual scour processes, debris, etc.):

2.5

0.6

1

Maximum exposure of the right abutment footing is at the US and DS ends.

80. Wingwalls:

Exist? Material? Scour Scour Exposure $\begin{aligned} & 81 . \\ & \text { Angle? Length? }\end{aligned}$ Condition? depth? depth?

USLWW:

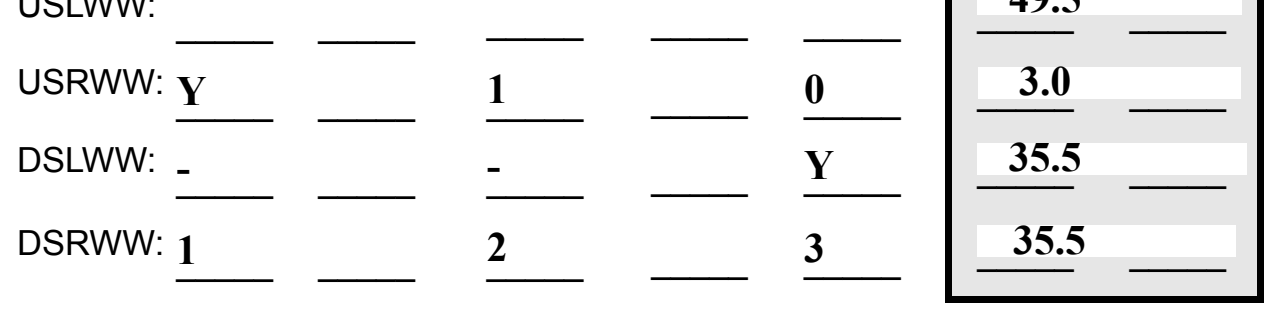

Wingwall materials: 1- Concrete; 2- Stone masonry or drywall; 3- steel or metal; 4- wood

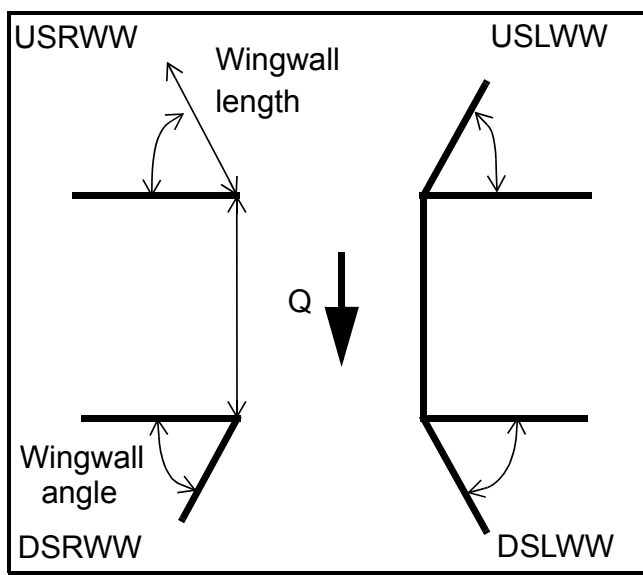

82. Bank / Bridge Protection:

\begin{tabular}{|l|l|l|l|l|l|l|c|c|}
\hline Location & USLWW & USRWW & LABUT & RABUT & LB & RB & DSLWW & DSRWW \\
\hline Type & $\mathbf{0 . 6}$ & $\mathbf{0}$ & $\mathbf{Y}$ & $\mathbf{1 . 5}$ & $\mathbf{1}$ & - & - & - \\
\hline Condition & $\mathbf{Y}$ & - & $\mathbf{1}$ & $\mathbf{0}$ & $\mathbf{2}$ & - & - & - \\
\hline Extent & $\mathbf{1}$ & - & $\mathbf{1}$ & $\mathbf{3}$ & $\mathbf{0}$ & $\mathbf{0}$ & $\mathbf{0}$ & $\mathbf{0}$ \\
\hline
\end{tabular}

Bank / Bridge protection types: 0- absent; 1-<12 inches; 2- < 36 inches; 3- < 48 inches; 4- < 60 inches; 
83. Wingwall and protection comments (eg. undermined penetration, unusual scour processes, etc.):

-
-
0
-
-
2
1
3
3
1
3

\section{Piers:}

84. Are there piers? Ma (Y or if $N$ type ctrl-n pr)

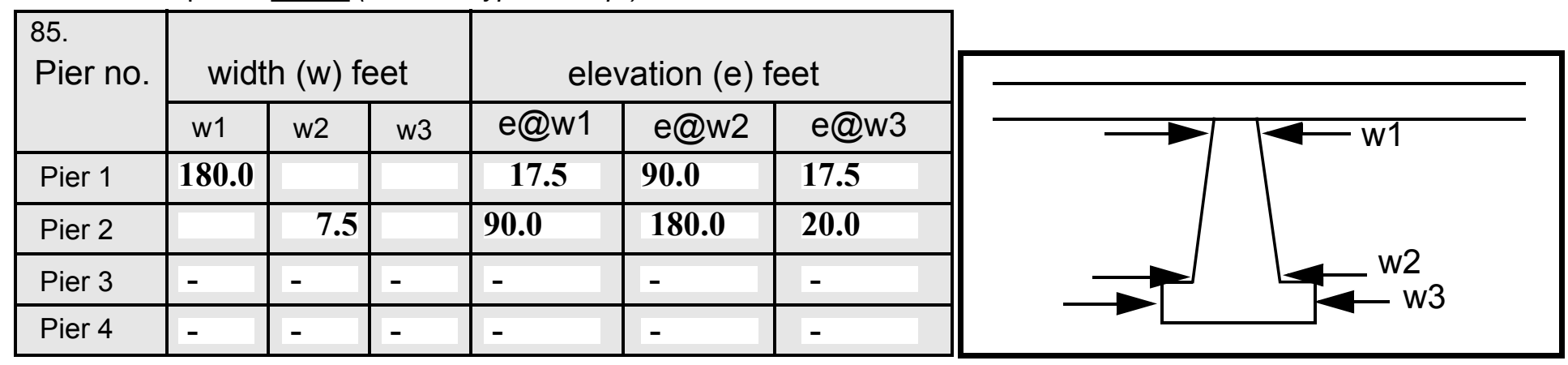

\begin{tabular}{|l|l|l|l|l|}
\hline Level 1 Pier Descr. & \multicolumn{1}{|c|}{1} & \multicolumn{1}{|c|}{2} & \multicolumn{1}{|c|}{3} & \multicolumn{1}{|c|}{4} \\
\hline 86. Location (BF) & ximum & with & rds the & \\
\hline 87. Type & scou & the & ends & \\
\hline 88. Material & r & abut & of & \\
\hline 89. Shape & dept & ment & the & \\
\hline 90. Inclined? & hs & ; & wing & N \\
\hline 91. Attack $\angle$ (BF) & are & scou & walls & - \\
\hline 92. Pushed & at & r & - & - \\
\hline 93. Length (feet) & - & - & - & - \\
\hline 94. \# of piles & the & dept & & - \\
\hline 95. Cross-members & cor- & hs & & - \\
\hline 96. Scour Condition & ner & decr & & - \\
\hline 97. Scour depth & junc- & ease & & - \\
\hline 98. Exposure depth & tions & towa & & - \\
\hline
\end{tabular}

LFP, LTB, LB, MCL, MCM, MCR, RB, RTB, RFP

1- Solid pier, 2- column, 3- bent

1-Wood; 2- concrete; 3- metal; 4- stone

1- Round; 2- Square; 3- Pointed

Y-yes; $N$ - no

$L B$ or $R B$

0- none; 1- laterals; 2- diagonals; 3- both

0- not evident; 1- evident (comment);

2- footing exposed; 3- piling exposed;

4- undermined footing; 5- settled; 6-failed 
99. Pier comments (eg. undermined penetration, protection and protection extent, unusual scour processes, etc.):

-
-
-
-
-
-
-
-
-
-

100.

\section{E. Downstream Channel Assessment}

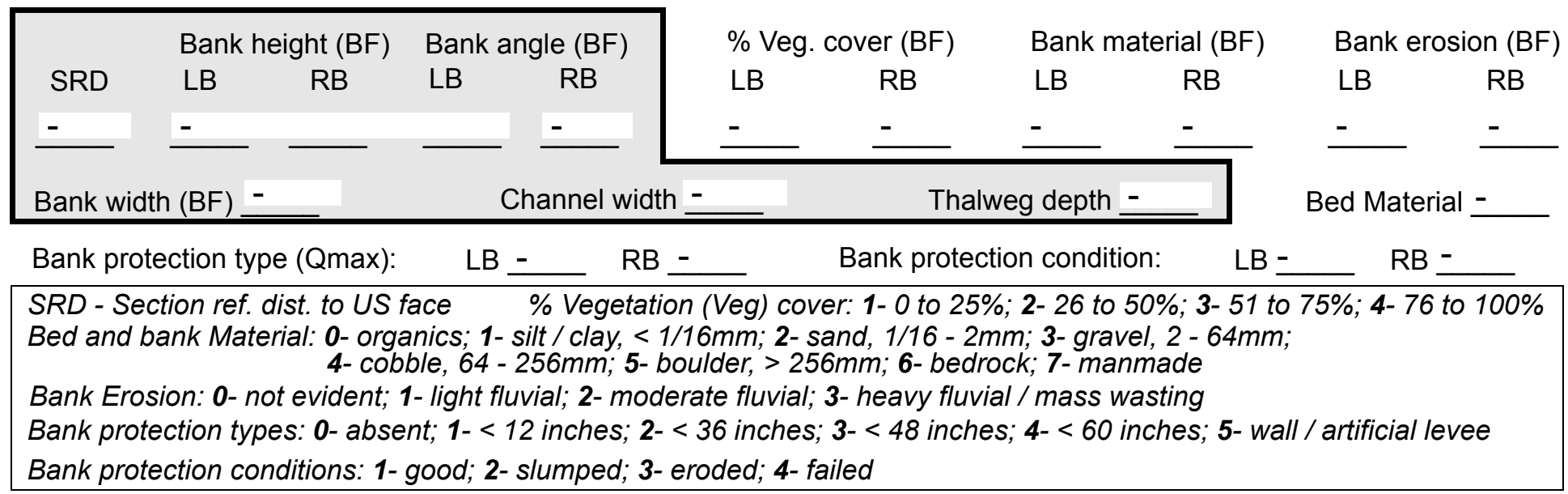

Comments (eg. bank material variation, minor inflows, protection extent, etc.):

$$
-
$$$$
-
$$$$
-
$$$$
-
$$$$
-
$$$$
-
$$$$
-
$$$$
-
$$$$
-
$$$$
-
$$$$
-
$$$$
-
$$

101. Is a drop structure present? _ ( or $N$, if $N$ type ctrl-n ds) 102. Distance: _ _ feet 103. Drop: -_ feet 104. Structure material: ___ (1- steel sheet pile; 2- wood pile; 3- concrete; 4- other) 105. Drop structure comments (eg. downstream scour depth):

$-$

$-$

$-$

\section{NO PIERS}


106. Point/Side bar present? (Y or $N$. if $N$ type ctrl-n pb)Mid-bar distance:

Mid-bar width:

Point bar extent: feet

(US, UB, DS) to feet (US, UB, DS) positioned $\underline{3}$ \%LB to $\underline{3}$ \%RB

Point or side bar comments (Circle Point or Side; note additional bars, material variation, status, etc.):

\section{3}

0

0

453

Is a cut-bank present? 3 3 (Yor if $N$ type ctrl-n $c b)$ Where? $\underline{\mathbf{2}}$ (LB or RB) Mid-bank distance: 1 Cut bank extent: 1 feet $\underline{\mathbf{T h}}$ (US, UB, DS) to $\underline{\text { e left feet ba }}$ (US, UB, DS)

Bank damage: $\mathbf{n k}$ (1- eroded and/or creep; 2- slip failure; 3- block failure)

Cut bank comments (eg. additional cut banks, protection condition, etc.):

protection extends 55 feet DS from bridge. Some bank protection exists beyond $55 \mathrm{ft}$ downstream with the embankment of town highway 44 along channel.

The right bank protection extends 20 feet DS to a concrete faced culvert within the bank.

Is channel scour present? (Y or if $N$ type ctrl-n cs)

Mid-scour distance:

Scour dimensions: Length Width Depth:

Positioned $\%$ LB to $\%$ RB

Scour comments (eg. additional scour areas, local scouring process, etc.):

Are there major confluences? $\mathbf{N}$ ( $Y$ or if $N$ type ctrl-n $m c)$

Confluence 1: Distance NO

Confluence 2: Distance $\underline{\text { STR }}$

Confluence comments (eg. confluence name):

RE
Enters on $\underline{\mathbf{D R}}$ (LB or RB)

Enters on $\underline{\mathbf{U C}}$ (LB or RB)
How many? -

Type $\mathbf{O P}$ (1- perennial; 2- ephemeral)

Type $\underline{\mathbf{T U}}$ (1- perennial; 2- ephemeral)

\section{F. Geomorphic Channel Assessment}

107. Stage of reach evolution

1- Constructed

2- Stable

3- Aggraded

4- Degraded

5- Laterally unstable

6- Vertically and laterally unstable 
108. Evolution comments (Channel evolution not considering bridge effects; See HEC-20, Figure 1 for geomorphic descriptors):
Y
5 UB
17
0
US
15
DS
0
25
23 


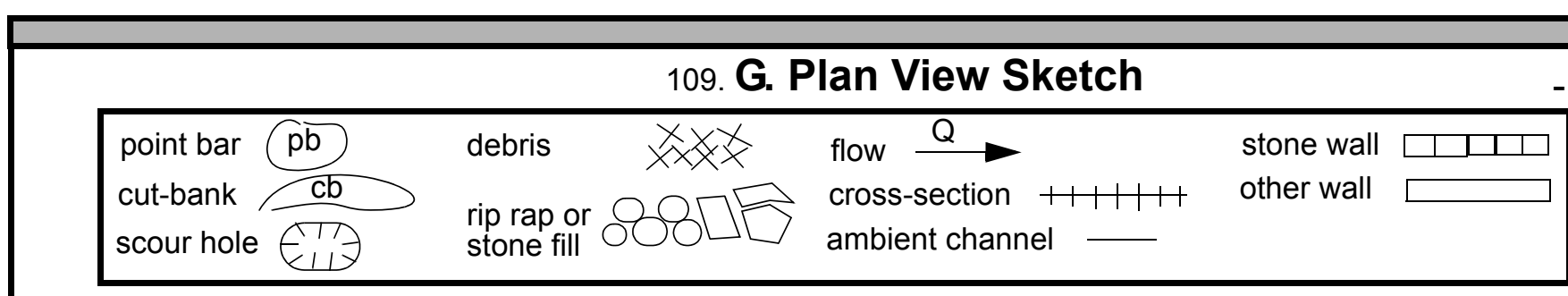

cut-bank $\mathrm{cb}$

scour hole rip rap or
stone fill stone fill cross-section $+1+1+1$ ambient channe other wall 
APPENDIX F:

SCOUR COMPUTATIONS 


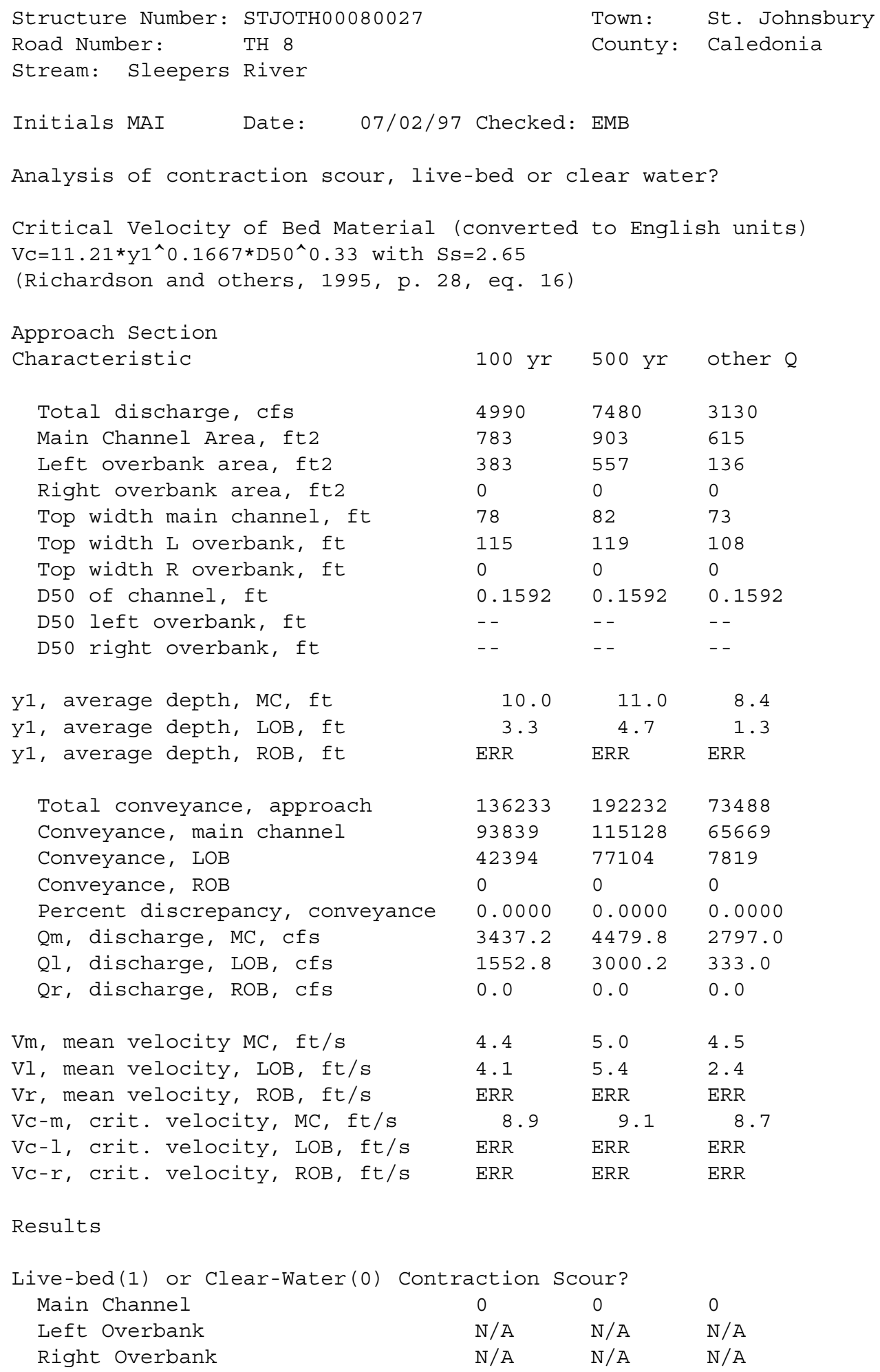


Clear water Contraction Scour in MAIN CHANNEL

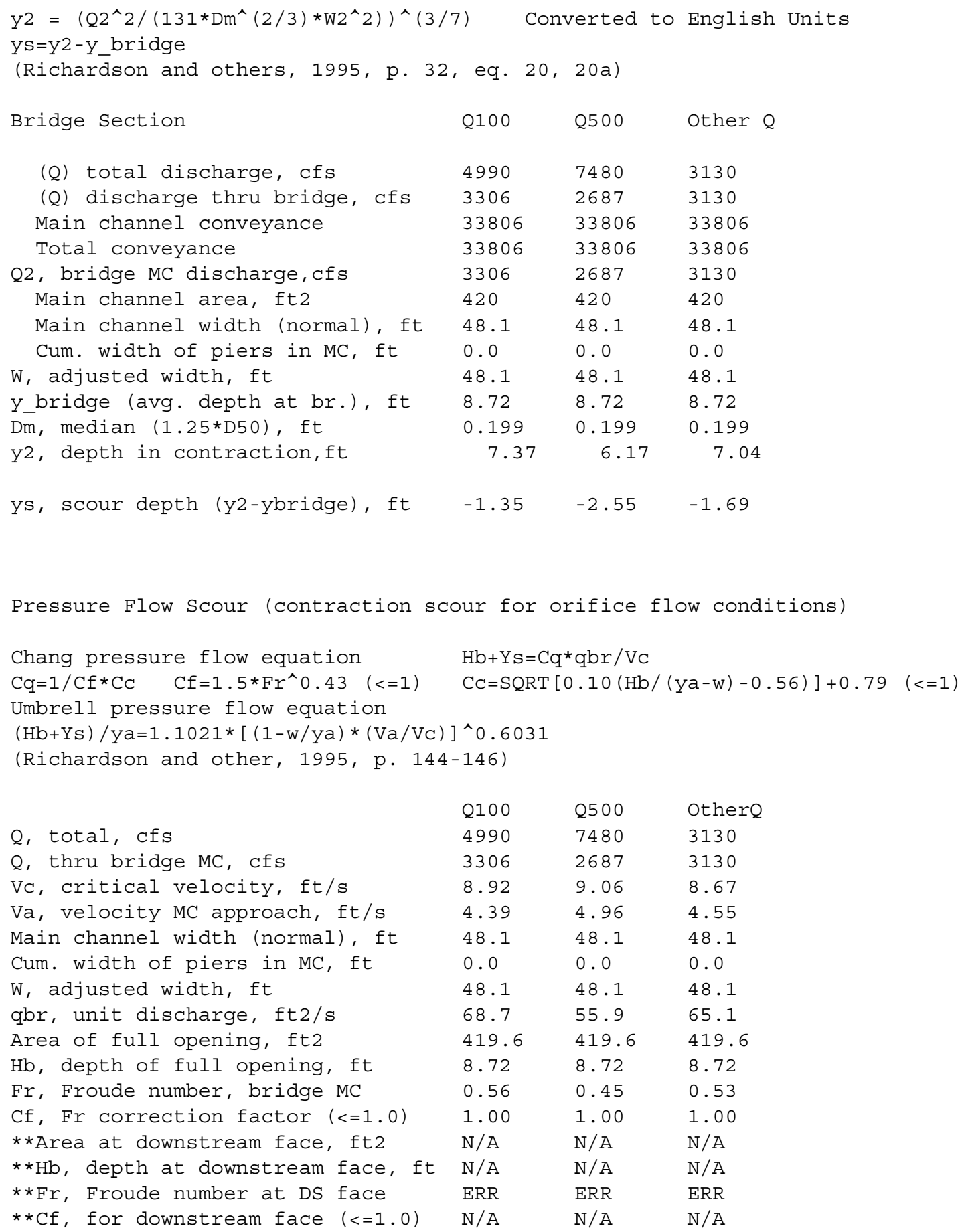




\begin{tabular}{|c|c|c|c|}
\hline Elevation of Low steel, ft & 498.3 & 498.3 & 498.3 \\
\hline Elevation of Bed, ft & 489.58 & 489.58 & 489.58 \\
\hline Elevation of Approach, ft & 502.9 & 504.39 & 500.68 \\
\hline Friction loss, approach, ft & 0.18 & 0.2 & 0.18 \\
\hline Elevation of WS immediately US, ft & 502.72 & 504.19 & 500.50 \\
\hline ya, depth immediately US, ft & 13.14 & 14.61 & 10.92 \\
\hline Mean elevation of deck, ft & 501.66 & 501.66 & 501.66 \\
\hline w, depth of overflow, ft $(>=0)$ & 1.06 & 2.53 & 0.00 \\
\hline Cc, vert contrac correction $(<=1.0)$ & 0.92 & 0.92 & 0.94 \\
\hline$* * \mathrm{Cc}$, for downstream face $(<=1.0)$ & ERR & ERR & ERR \\
\hline ur w/Chang equation, ft & -0.33 & -2.00 & -0.77 \\
\hline Ys, scour w/Umbrell equation, ft & 0.25 & 1.26 & -0.56 \\
\hline
\end{tabular}

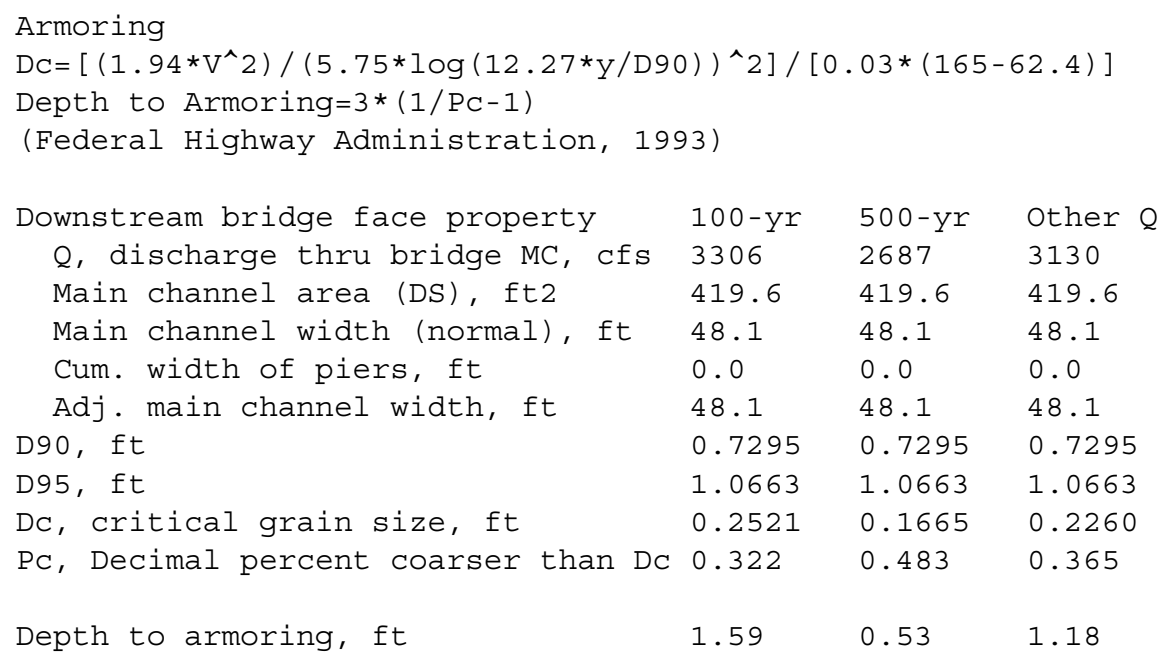

Abutment Scour

Froehlich's Abutment Scour

$\mathrm{Ys} / \mathrm{Y} 1=2.27 * \mathrm{~K} 1 * \mathrm{~K} 2 *\left(\mathrm{a}^{\prime} / \mathrm{Y} 1\right)^{\wedge} 0.43 * \mathrm{Fr} 1^{\wedge} 0.61+1$

(Richardson and others, 1995, p. 48, eq. 28)

\begin{tabular}{|c|c|c|c|c|c|c|}
\hline \multirow[b]{2}{*}{ Characteristic } & \multicolumn{2}{|c|}{ Left Abutment } & \multicolumn{4}{|c|}{ Right Abutment } \\
\hline & 100 yr & 500 yr & ther $Q$ & $100 \mathrm{yr}$ & 0 yr & ther $\mathrm{Q}$ \\
\hline (Qt), total discharge, cfs & 4990 & 7480 & 3130 & 4990 & 7480 & 3130 \\
\hline a', abut.length blocking flow, ft & 128.6 & 132.7 & 122.5 & 16.2 & 20.1 & 11.1 \\
\hline Ae, area of blocked flow ft 2 & 319.6 & 346.6 & 221.8 & 68.3 & 66.6 & 48.8 \\
\hline $\begin{array}{l}\text { Qe, discharge blocked abut., cfs } \\
\text { (If using Qtotal_overbank to obt }\end{array}$ & $\operatorname{ain} \mathrm{Ve}$ & ve Qe & $\begin{array}{l}626 \\
\text { ank and }\end{array}$ & enter $\mathrm{V}$ & ad $\operatorname{Fr}$ & $\begin{array}{r}127.7 \\
\text { ually) }\end{array}$ \\
\hline $\mathrm{Ve},(\mathrm{Qe} / \mathrm{Ae}), \mathrm{ft} / \mathrm{s}$ & 3.96 & 5.19 & 2.82 & 2.53 & 2.92 & 2.62 \\
\hline ya, depth of $f / p$ flow, ft & 2.49 & 2.61 & 1.81 & 4.22 & 3.31 & 4.40 \\
\hline $\begin{array}{l}\text {--Coeff., K1, for abut. type (1.0, } \\
\text { K1 }\end{array}$ & 0.82 & 0.82 & $\begin{array}{r}\mathrm{w} / \\
0.82\end{array}$ & 0.82 & 0.82 & 0.82 \\
\hline
\end{tabular}




\begin{tabular}{|c|c|c|c|c|c|c|}
\hline theta & 45 & 45 & 45 & 135 & 135 & 135 \\
\hline K2 & 0.91 & 0.91 & 0.91 & 1.05 & 1.05 & 1.05 \\
\hline Fr, froude number $\mathrm{f} / \mathrm{p}$ flow & 0.354 & 0.399 & 0.370 & 0.195 & 0.217 & 0.220 \\
\hline ys, scour depth, ft & 14.73 & 16.35 & 12.09 & 9.66 & 8.87 & 9.50 \\
\hline \multicolumn{7}{|l|}{$\begin{array}{l}\text { HIRE equation }\left(\mathrm{a}^{\prime} / \mathrm{ya}>25\right) \\
\mathrm{ys}=4{ }^{*} \mathrm{Fr}^{\wedge} 0.33^{*} \mathrm{y} 1 * \mathrm{~K} / 0.55\end{array}$} \\
\hline$a^{\prime}$ (abut length blocked, ft) & 128.6 & 132.7 & 122.5 & 16.2 & 20.1 & 11.1 \\
\hline y1 (depth f/p flow, ft) & 2.49 & 2.61 & 1.81 & 4.22 & 3.31 & 4.40 \\
\hline$a^{\prime} / y 1$ & 51.75 & 50.81 & 67.66 & 3.84 & 6.07 & 2.52 \\
\hline Skew correction (p. 49, fig. 16) & 0.80 & 0.80 & 0.80 & 1.10 & 1.10 & 1.10 \\
\hline Froude no. f/p flow & 0.35 & 0.40 & 0.37 & 0.20 & 0.22 & 0.22 \\
\hline $\begin{array}{c}\text { Ys w/ corr. factor } \mathrm{Kl} / 0.55: \\
\text { vertical }\end{array}$ & 10.26 & 11.22 & 7.59 & ERR & ERR & ERR \\
\hline vertical w/ ww's & 8.42 & 9.20 & 6.22 & ERR & ERR & ERR \\
\hline spill-through & 5.65 & 6.17 & 4.17 & ERR & ERR & ERR \\
\hline
\end{tabular}

Abutment riprap sizing

Isbash Relationship

$\mathrm{D} 50=\mathrm{Y} * \mathrm{~K} * \mathrm{Fr} r^{\wedge} 2 /(\mathrm{SS}-1)$ and $\mathrm{D} 50=\mathrm{Y} * \mathrm{~K} *\left(\mathrm{Fr} r^{\wedge}\right)^{\wedge} 0.14 /(\mathrm{SS}-1)$

(Richardson and others, 1995, p112, eq. 81,82)

\begin{tabular}{|c|c|c|c|c|c|c|}
\hline Characteristic & Q100 & Q500 & Other Q & Q100 & Q500 & Other $\mathrm{Q}$ \\
\hline Fr, Froude Number & 0.56 & 0.45 & 0.53 & 0.56 & 0.45 & 0.53 \\
\hline$y$, depth of flow in bridge, ft & 8.72 & 8.72 & 8.72 & 8.72 & 8.72 & 8.72 \\
\hline Median Stone Diameter for ripra & : left & atment & & right & abutment & ft \\
\hline Fr<=0.8 (vertical abut.) & 1.69 & 1.09 & 1.51 & 1.69 & 1.09 & 1.51 \\
\hline Fr>0.8 (vertical abut.) & ERR & ERR & ERR & ERR & ERR & ERR \\
\hline
\end{tabular}


